PNL-5870

UC-85

\title{
A Method for Assigning Sites to Projected Generic Nuclear Power Plants
}

G. M. Holter
W. L. Purcell
M. E. Schutz
J. R. Young

July 1986

Prepared for the U.S. Department of Energy under Contract DE-ACO6-76RLO 1830

Pacific Northwest Laboratory

Operated for the U.S. Department of Energy Battelle Memorial Institute 


\title{
DISCLAIMER
}

This report was prepared as an account of work sponsored by an agency of the United States Government. Neither the United States Government nor any agency thereof, nor any of their employees, makes any warranty, express or implied, or assumes any legal liability or responsibility for the accuracy, completeness, or usefulness of any information, apparatus, product, or process disclosed, or represents that its use would not infringe privately owned rights. Reference herein to any specific commercial product, process, or service by trade name, trademark, manufacturer, or otherwise, does not necessarily constitute or imply its endorsement, recommendation, or favoring by the United States Government or any agency thereof. The views and opinions of authors expressed herein do not necessarily state or reflect those of the United States Government or any agency thereof.

\author{
PACIFIC NORTHWEST LABORATORY \\ operated by \\ BATTELLE \\ for the \\ UNITED STATES DEPARTMENT OF ENERGY \\ under Contract DE-AC06-76RLO 1830
}

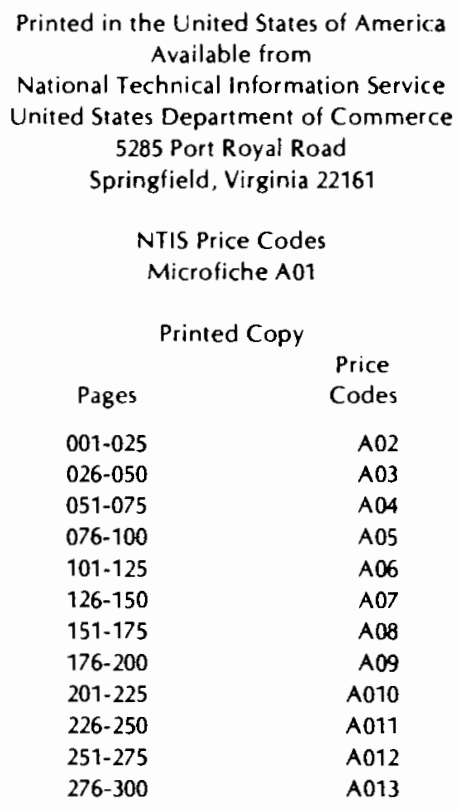


A METHOD FOR ASSIGNING SITES TO PROJECTED GENERIC NUCLEAR POWER PLANTS
G. M. Holter
W. L. Purcell
M. E. Schutz
J. R. Young

July 1986

Prepared for

U.S. Department of Energy

under Contract DE-AC06-76RLO 1830

Pacific Northwest Laboratory

Richland, Washington 99352 
- 


\section{ABSTRACT}

Pacific Northwest Laboratory developed a method for forecasting potential locations and startup sequences of nuclear power plants that will be required in the future but have not yet been specifically identified by electric utilities. Use of the method results in numerical ratings for potential nuclear power plant sites located in each of the 10 federal energy regions. The rating for each potential site is obtained from numerical factors assigned to each of 5 primary siting characteristics: 1) cooling water availability, 2) site land area, 3) power transmission land area, 4) proximity to metropolitan areas, and 5) utility plans for the site. The sequence of plant startups in each federal energy region is obtained by use of the numerical ratings and the forecasts of generic nuclear power plant startups obtained from the EIA Middle Case electricity forecast. Sites are assigned to generic plants in chronological order according to startup date. 


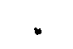




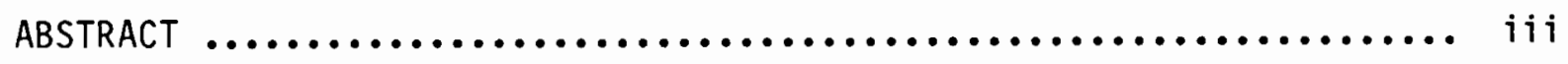

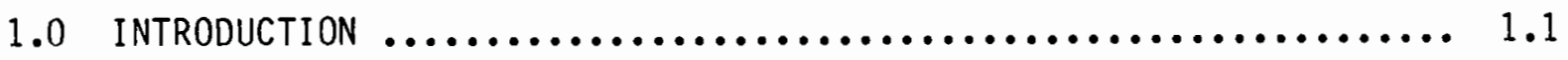

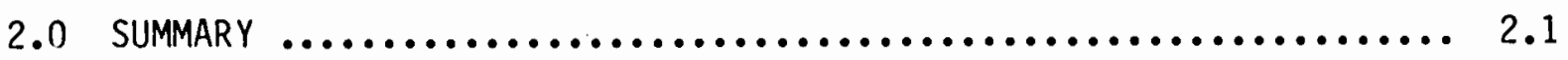

3.0 DESCRIPTION OF METHOD $\ldots \ldots \ldots \ldots \ldots \ldots \ldots \ldots \ldots \ldots \ldots \ldots \ldots \ldots \ldots \ldots . . \ldots \ldots$

3.1 STUDY OBJECTIVES $\ldots \ldots \ldots \ldots \ldots \ldots \ldots \ldots \ldots \ldots \ldots \ldots \ldots \ldots \ldots \ldots \ldots \ldots \ldots \ldots$

3.2 BASES FOR DEVELOPMENT OF SITE-ASSIGNMENT METHOD $\ldots \ldots \ldots \ldots . .2$

3.2.1 Basic Study Strategy $\ldots \ldots \ldots \ldots \ldots \ldots \ldots \ldots \ldots \ldots \ldots . .2$

3.2.2 Site-Information Sources $\ldots \ldots \ldots \ldots \ldots \ldots \ldots \ldots \ldots, 3.3$

3.2.3 Characteristics Considered in Analysis of Sites ..... 3.4

3.3 SITE ASSIGNMENT METHOD AND RESULTS $\ldots \ldots \ldots \ldots \ldots \ldots \ldots \ldots . . \ldots .7$

3.3.1 Site Assignment Method $\ldots \ldots \ldots \ldots \ldots \ldots \ldots \ldots \ldots \ldots . . .6$

3.3.2 Base Case for Site Selections $\ldots \ldots \ldots \ldots \ldots \ldots \ldots \ldots . . .12$

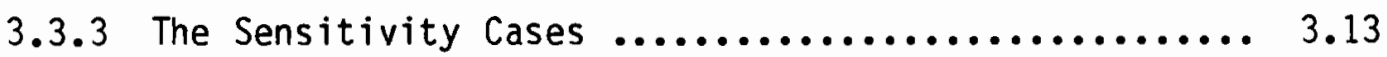

4.0 CONCLUSIONS AND RECOMMENDATIONS $\ldots \ldots \ldots \ldots \ldots \ldots \ldots \ldots \ldots \ldots \ldots . . \ldots \ldots$

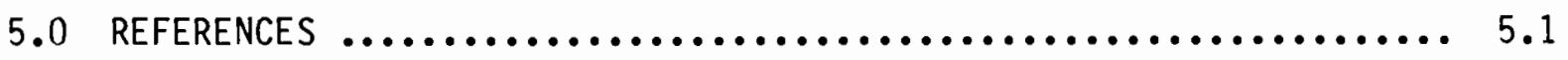

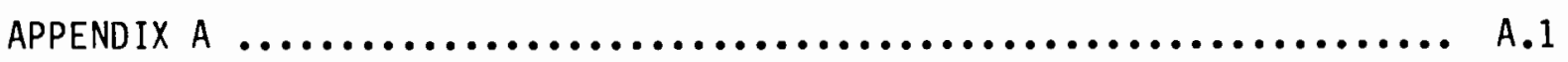

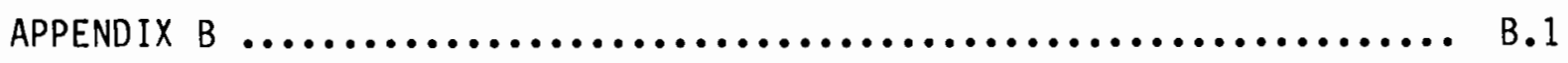

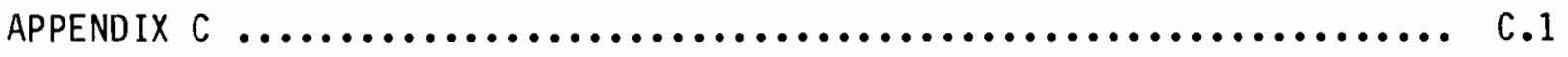




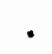




\subsection{INTRODUCTION}

In the U.S., the majority of the commercial spent nuclear fuel that will ultimately require disposal has not yet been generated. Therefore, planning for the management and disposal of commercially generated spent fuel must be based primarily on projections of future discharges from nuclear power plants. This report describes a method for assigning sites to projected generic nuclear power plants. The work, funded by the Department of Energy (DOE) Office of Civilian Radioactive Waste Management (OCRWM), was performed by the Pacific Northwest Laboratory (PNL).

The DOE Energy Information Administration (EIA) annually publishes projections of electric power expected to be generated by nuclear power plants. Several growth rates that are assumed to approximate future requirements for electric power in the U.S. are used to make the projections (Gielecki et al. 1985). The DOE-OCRWM bases its programs and activities for interim storage and ultimate disposal of nuclear wastes on these projections. Detailed spent-fuel discharge projections corresponding to the EIA electric-power growth projections have been developed to provide specific plant-by-plant information needed to perform a variety of detailed analyses (Heeb et al. 1986). To effectively bracket the most likely forecast, two EIA growth scenarios were chosen as bases for developing plant-specific spent fuel discharge projections: the Middle Case and the No New Orders Case.

In developing plant-specific spent-fuel discharge projections that correspond to the EIA Middle Case, a number of postulated generic nuclear power plants in excess of the currently planned and existing plant population were required, starting in 2001 , to meet the overall installed electricity-generating capacities used in the EIA projections. Plant types consistent with currently existing nuclear power plants were chosen as representative generic plants. Using this approach permits detailed spent-fuel discharge projections to be developed in the same manner for both generic plants and existing plants. Projections based on 1984 end-of-calendar-year data required the addition of 167 generic nuclear power plants for the years from 2001 and 2020 to maintain consistency with the EIA Middle Case projections (Heeb et al. 1986). 
No specific sites are designated for the generic plants because they are not included in the utilities' plans. However, without identification of specific sites, logistic analyses involving spent fuel discharged from the generic power plants, which comprise half the total reactor population included in the EIA Middle Case, are difficult to accomplish. Therefore, to provide a meaningful basis for analyses using the EIA Middle Case growth scenario, this study was undertaken to develop a reasonable and consistent method for assigning projected generic power plants to specific geographical sites.

The number of current, planned, and potential future sites for nuclear power plants was summarized from information published by Briggs et al. (1978) and Burwell and Lane (1980). The summarized information was then used to develop an ordered list of sites for locating generic power plants within each of the ten federal energy regions.

The siting limitations that were taken into account in assigning the projected generic power plants to specific sites are primarily related to the pertinent physical characteristics of each site. The generic plants are distributed, as needed, among the ten federal energy regions to maintain an appropriate regional balance in electricity generating capacity from nuclear power plants (Heeb et al. 1986).

Within each region, the number of generic plants assigned to any single site is limited to prevent exceeding a reasonable capacity at the site. However, efforts are made to limit the proliferation of sites by providing a preference for multiple-plant siting rather than identifying a unique site for every required generic power plant. The principal physical characteristics considered in developing the ordered list of sites include:

1. cooling-water availability

2. site land area

3. power transmission land requirements

4. proximity to major metropolitan areas

5. utility plans for the site.

The postulated site-assignment information provided in this report, including the sites for the generic power plants, can be used in plant-specific logistics analyses. However, the siting rationale that is described is based 
on the selection of each site from all available sites within a federal energy region. Actual future siting decisions made by a number of separate, independently-acting utilities will differ in detail, but should produce results that are essentially similar to those presented here.

In particular, the site selection information presented in this report provides general site locations based on the probability of selection as actual sites for nuclear power plants. However, because all possible siting characteristics were not considered, specific sites selected by the utilities and the sequences of plant startups may be different. For example, a utility may select new sites in a sequence that differs from the sequence shown in this report because it has a need for electricity generation in a specific part of its service area. The site selection information provided in this report should not be interpreted as an exact forecast of the locations and startup sequences for future nuclear power plants. Use of this information for certain types of analyses (e.g., route-specific transportation assessments) is inappropriate. 


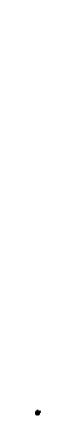




\subsection{SUMMARY}

A method has been developed for use in forecasting the location of sites for, and the startup sequence of, required future nuclear power plants that have not been specifically identified by electric utilities (i.e., generic plants). The method provides information about plant startup times and site locations. This information is needed when performing logistics analyses beyond the time period currently encompassed by the utilities' planning efforts.

Use of the method results in a numerical rating for each potential site located in each of the 10 federal energy regions. The numerical rating for each site is obtained by suming the products obtained by multiplying a siting1 imitation factor by a site-description factor for each of 5 siting characteristics. The characteristics considered are:

1. cooling water availability

2. site land area

3. power transmission land requirements

4. proximity to metropolitan areas

5. utility plans for the site.

The siting-limitation and site-description factors are designed so that products with low numerical values are associated with desirable sites (i.e., the most desirable site will have the lowest numerical rating).

The sequence of generic plant startups in each federal energy region is obtained by use of the site numerical ratings and the forecast of generic plant startups obtained from the EIA Middle Case electricity forecast. Sites are assigned to the generic plants in chronological order according to startup date. The site with the lowest numerical rating is assigned to the first generic plant startup, except in cases where this would result in multiple startups on the same site within a specified minimum delay period between startups. 
The method has been used to define a base case and six sensitivity cases that illustrate changes in the sequence of generic power plant requirements caused by changes in the EIA electricity forecasts or in the relative values of the siting characteristics. The plant startup sequences for the seven cases are presented in Tables C.I and C.2 of Appendix C. The primary conclusions resulting from analysis of these cases are:

- A change in the demand for electricity may change the projected sequence of generic plant startups. This change could alter the effects of the assumed minimum permissible 2-year delay period for plant startups at a multiple-plant site and, therefore, result in a different sequence of site assignments.

- Because the numerical ratings of the sites and the resulting siting sequence are very dependent on the relative values selected for the siting characteristics, care must be exercised when selecting relative values. 


\subsection{DESCRIPTION OF METHOD}

EIA Middle Case projections for the amount of electricity generated at nuclear power plants include power generated at generic (i.e., currently unplanned) nuclear plants that are assumed to begin operations after the year 2000. These generic plants are included, as appropriate, to ensure that required power generation capacities will be maintained. Because these generic plants are not included in utility plans, site locations have not been selected. However, analyses of issues such as waste-transportation distances must consider the location of these generic plants. This study was undertaken to develop a method for assigning specific sites to the generic power plants so that needed logistics analyses can be performed.

The specific objectives of this study are described below. A discussion of the bases used for development of the method, including the basic strategy or approach employed and the information used in the analysis, follows. The sensitivity of the results to changes in the study assumptions is also discussed. A description of how the method was applied to spent-fuel projections corresponding to the EIA Middle Case growth projection and the results that were obtained conclude this chapter.

\subsection{STUDY OBJECTIVES}

The primary objectives of this study were:

1. to develop a method for assigning sites to projected generic nuclear power plants

2. to provide the results of applying this method to the EIA Middle Case nuclear power plant growth projections.

Results are provided for both the 1984 and 1985 EIA projections. The site assignments are separated by federal energy region to correspond with the regional electricity requirements included in the EIA projections.

The site assignments produced by this method must be reasonably similar to actual siting actions if they are to provide a realistic basis for subsequent site-specific analyses. Therefore, site-selection decisions using the method 
must account for factors such as the physical characteristics and limitations of the sites and co-location of a given plant with other plants on the same site. The siting limitations considered during the site selection process are discussed in Section 3.2.

A secondary objective of the study was to determine the sensitivity of the the method to changes in the requirements for generic plants to meet the nuclear power plant capacity projections. If, for example, minor changes in the schedule for generic plants in a given federal energy region produce major differences in the sites selected by the process, the results would probably vary considerably from year to year as the EIA projections and the underlying data are updated. This variability could limit the usefulness of the siteselection method as a basis for waste-management system logistics calculations.

Meeting the study objectives required identifying pertinent information on potential generic power plant sites and developing a set of rules to be applied to the site information so the required site assignments could be determined. The bases for development of the site-assignment method and its application are described in the remaining sections of this chapter.

\subsection{BASES FOR DEVELOPMENT OF SITE-ASSIGNMENT METHOD}

The basic strategy employed to identify sites, the sources used for information on the sites considered, and the siting limitations considered in the analysis of the sites are discussed in this section.

\subsubsection{Basic Study Strategy}

Consideration of sites previously identified as candidates for nuclear power plant locations was the basic strategy adopted for this study. Such sites include those with currently operating plants, sites selected by the utilities for plants that have subsequently been canceled, and other sites identified in previous studies as potential nuclear power plant sites. The sites considered in this study are primarily from the first two categories, with sites from the latter category added only when needed to provide sufficient siting capacity for all the generic plants projected to be located in a federal energy region. 
Implicit in this strategy is the assumption that future siting decisions will include some preference for locating nuclear power plants on sites already used for such plants, rather than using a new site for each new plant that is built. This preference is one of the factors considered in the site-assignment method described below.

\subsubsection{Site-Information Sources}

The data on sites that have been or could be used for locating nuclear power reactors were drawn primarily from several related studies that evaluated the feasibility of using existing sites to meet future nuclear power siting needs (Briggs et al. 1978, Burwell and Lane 1980). These studies, which were undertaken at a time when the utilities had more ambitious plans for building nuclear power plants, revealed that the sites identified by the utilities could provide for substantial growth in the nuclear power industry and that additional sites, if needed, could be identified to supplement those identified by the utilities.

The sites identified by the utilities (Briggs et al. 1978) provided sufficient capacity to locate existing, planned, and potential generic nuclear power plants in most federal energy regions. Insufficient site capacities were identified for the generic plant requirements in Regions 1, 3, and 4. The 1ist of possible sites in Regions 3 and 4 was expanded by including additional sites identified by Burwell and Lane (1980). The longitude and latitude of the additional sites were not explicitly reported by Burwell and Lane (1980), and were estimated using local site area maps and larger scale maps in a commercial atlas (Rand McNally and Company 1983). However, Burwell and Lane (1980) identified no additional sites for Region 1. Compensation for the insufficiency in identified sites in Region 1 was made by assuming that (two) additional plants would be built in the adjacent Region 2 and that the needed electricity would be transmitted into Region 1.

Information on the actual sites of current nuclear power plants and the utilities' plans for siting future plants was taken from the spent fuel data base used to project the requirements for generic plants (Heeb et al. 1986). This information was used to identify the potential plant locations already 
occupied by existing plants and plants planned by the utilities. This measure was taken to avoid assigning a generic plant to a site that has no more capacity.

\subsubsection{Characteristics Considered in Analysis of Sites}

The method developed in this study for siting generic nuclear power plants includes a scheme for creating a listing of sites that is prioritized in terms of their potential for receiving new generic plants. Use of this prioritization scheme results in separate listings of potential sites located in each of the federal energy regions. The site characteristics that are important for creating a priority listing were identified, and the data necessary for defining those characteristics were obtained. The characteristics that were judged to be of primary importance and, as a result, were included in this study are described in the following paragraphs.

Site Identification. Site location and other general site information was used to identify potential sites and to place them in the appropriate federal energy regions. Also, the geographic coordinates (i.e., longitude and latitude) of the potential sites were identified. These coordinates can be used in location-specific logistics analyses of the generic plants.

Site Capacity. Estimates of the electrical generating capacity that could be installed on each site were derived from information published by Briggs et al. (1978) and Burwell and Lane (1980). By subtracting the capacities of the currently sited plants (i.e., those currently operating or planned by the utilities), the available capacity for generic plants can be determined for each site. Furthermore, because the generic reactors are uniformly rated at 1100 MWe each (Heeb et al. 1986) the available capacity at each site (in MWe) can be divided by 1100 MWe to determine the number of generic plants that can be located on the site.

Cooling Water Availability. The availability of adequate cooling water is a primary measure of the suitability of a site for the construction or expansion of electric power generation plants. Potential limitations in the availability of adequate cooling water were reported by Briggs et al. (1978), and were included in the site data considered in this study. Most of the sites 
considered in this study had no reported limitations in cooling water availability. However, limitations were noted for some individual sites. At the sites where limitations were noted, natural limits in the amount of available water were indicated at two levels:

1. marginal shortfalls that could probably be circumvented without too much difficulty

2. more serious natural water limitations that could require substantial measures to overcome.

Limitations in water availability caused by current water allocations were also noted.

Because of the importance of cooling water to the successful operation of a nuclear power plant, the availability of adequate water supplies was judged to be the most important discriminator among sites within a given federal energy region. Therefore, the factors considered, available water supplies had the largest impact on the priority ratings given to the individual sites. Limitations caused by water allocations were considered to be numerically equal to marginal physical limitations, because water allocation shortages were judged to be less severe than serious physical limitations in water availability.

Site Land Area. Inadequate land area could limit possible expansion of power generation capacity at a site. In general, the sites considered in this study were determined to have adequate land area to handle the expansions considered. However, some sites would require additional land to reach their estimated full capacity. These sites were given a lower priority than those that already had sufficient land area, although it was assumed that suitable additional land could be obtained, if needed.

The availability of sufficient land area for expansion of site power-generation capacity was considered in the calculations to be an important discriminator among sites, although not as important as the availability of adequate water resources. This conclusion is based on the judgment that obtaining additional land area for site expansion is not as difficult as circumventing shortages in available cooling water. 
Power Transmission Land Requirements. Improvements along power transmission corridors would be required in many cases to allow expansion of site power-generation capacity. Estimates of requirements for such improvements were reported by Briggs et al. (1978) and Burwell and Lane (1980).

In this study, the need for improvements along power transmission corridors was considered to be one of the least important of the factors used to discriminate among sites. This relative degree of insensitivity results because improvements to power-transmission corridors are relatively easy and inexpensive when compared with the improvements that may be required at a site to cope with cooling water shortages or to obtain additional land area for power plant construction.

Proximity to Metropolitan Areas. The distance of a nuclear power plant site from metropolitan areas requires special attention because the desirability of a site is not a linear function of that distance. Instead, a site has maximum desirability at an intermediate distance of perhaps 20 to $50 \mathrm{miles}$ from the nearest metropolitan area. Also, the desirability is a function of the number of nearby metropolitan areas.

The desirability of an intermediate distance results from a balance of the following two opposing factors:

1. the desire to minimize potential radiation doses to the general public and concern about the effects of potential nuclear accidents

2. the desire to minimize the economic and socioeconomic costs of providing the power.

In general, radiation doses and public concern decrease as the distance from a nuclear-plant site to a metropolitan center increases. In contrast, the economic and socioeconomic costs increase as the distance from a site to metropolitan center increases. The latter impact results primarily from the longer travel distances for both plant construction and operating personnel and the increased probability that there will be significant socioeconomic impacts on small communities near the plant site. Also, as the distance between the site and the metropolitan centers increases, the costs of construction and operation of transmission facilities usually increase because most of the electricity 
will be used in the nearest load center--usually the nearest metropolitan center. In this report, the merits of each site in relation to metropolitan proximity were determined by counting the number of the 100 largest metropolitan areas in the U.S. that are within 50 miles of each potential site (Briggs et al. 1978).

The proximity to metropolitan areas was considered to be a moderately important discriminator among sites, since it represents the primary public concerns about nuclear power plants--the effects of radiation doses and the socioeconomic effects.

Utility Plans for a Site. In this study, consideration generally was limited to sites already identified by utilities for construction of nuclear power plants (Briggs et a1. 1978), although some of these sites are not included in current utility plans. Use of sites already identified by utilities should be preferred to the use of new sites because:

1. Comprehensive utility studies, which include the siting factors considered important by the utilities, were used to identify these sites.

2. Licensing and construction of plants at many of these sites should cost considerably less than at new sites because of previous expenditures for site characterization, licensing, and, in some cases, initial construction.

However, as mentioned in Section 3.2.2, additional new sites were included in several federal energy regions because the sites identified by utilities do not have sufficient capacity to accommodate the needed additional generic plants. These new sites are rated less desirable than sites already identified by the utilities.

The utility plans for use of the sites were considered to be moderately important when differentiating among sites.

\subsection{SITE ASSIGNMENT METHOD AND RESULTS}

This section describes the site assignment method used for the generic nuclear power plants and presents the results of applying that method. The 
results are analyzed to determine the sensitivity of the results to the differ-ences in the assumptions for several cases.

\subsubsection{Site Assignment Method}

Selection of a nuclear power plant site requires comparison of the charac-teristics at a number of potential sites to determine which site has the most favorable balance of environmental, socioeconomic, economic, and public-safety impacts. This selection process starts with a general analysis to identify the most desirable potential sites that are in the same federal energy region and are proximate to the load center requiring additional electricity. Through a process of elimination, less desirable areas are rejected, preferred areas are identified, candidate sites in the preferred areas are identified and evaluated, and, finally, the preferred-candidate site(s) are identified by comparing the candidate sites in terms of the siting requirements defined by utility and governmental requirements.

The site-assignment method selected for this study parallels the final step of the site-selection method described above--the identification of the preferred sites for a series of generic nuclear power plants to be built in the period from 1986 to 2020. The initial steps in the site selection process (i.e., identification of the preferred siting lands, identification of the candidate sites, and characterization of those sites) have al ready been performed by the electric utilities and are not repeated in this study. Numerous candidate sites were identified and described in the period from 1960 to 1975 when the electricity load forecasts indicated a need for many more nuclear power plants than have actually been required.

The site assignment method determines the order in which the sites are selected within each federal energy region by use of a site rating that is calculated for each candidate site. This rating is a numerical value that is based on general site characteristics. The rating procedure is designed so that sites with low numerical ratings are considered to be desirable.

Analysis of general siting requirements for nuclear power plants indicates that six general characteristics are primary determinants of site merit. As described in Section 3.2.3, these six characteristics are: 
1. site capacity

2. cooling water availability

3. site land area

4. power transmission land requirements

5. proximity to metropolitan areas

6. utility plans for the site.

These characteristics, which were discussed previously, are used in the general process shown in Figure 3.1 to determine the order in which construction sites are selected.

In the first step, the case-input information and assumptions are defined. Case-input information and assumptions consist primarily of a description of each candidate site, a forecast of the power plant requirements for each federal energy region, a delay factor defined as the minimum permissible time period between startup dates for multiple plants at a single site, and relative values for each of the site rating characteristics listed above.

In the second step, the number of additional power plants that can be built at each site is determined by dividing the available site capacity (i.e., the capacity beyond that already used by current or utility-planned plants) by 1100 MWe, which the assumed capacity of the generic power plants (Heeb and Libby 1985). The available additional site capacity is equal to the total site capacity in the site description minus the operating plant capacity forecasted for the year 2000. Numerical values resulting from this calculation are rounded to the nearest whole number.

In the third step, the rating for each site is calculated using the following equation:

$$
\text { Rating }=\sum_{1}^{5} \text { (site limitation factor)(site description factor) }
$$

where: The site limitation factor is the relative importance of a site characteristic when compared with the other characteristics expressed as a numerical value. 


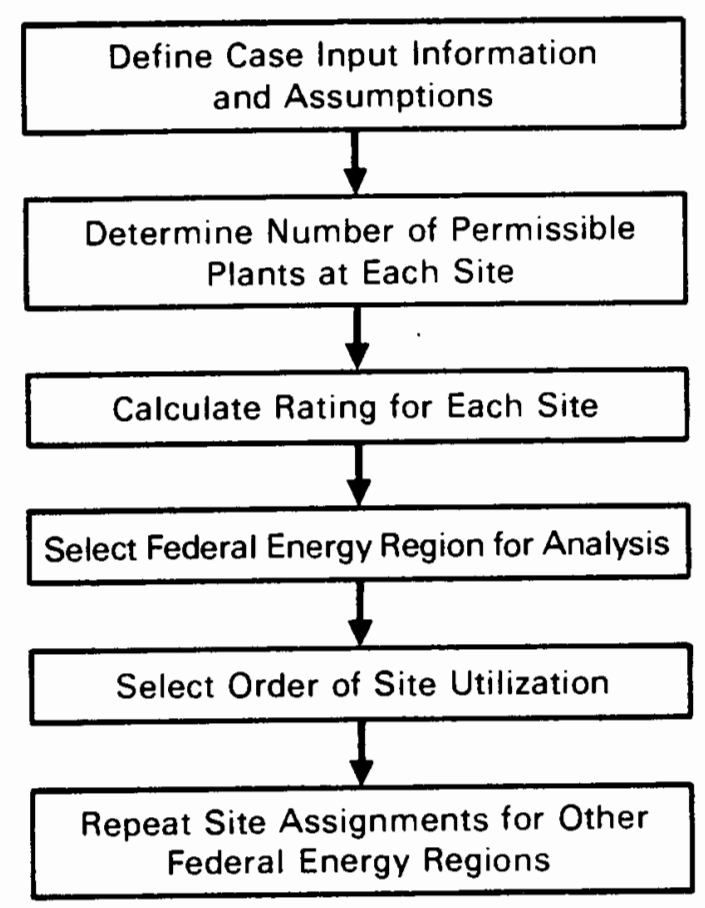

FIGURE 3.1. General Site Assignment Method

The site description factor is a numerical value determined by the physical description of the site for the siting characteristic being evaluated.

This calculation is demonstrated by use of the example site limitation factors and site description factors shown in Table 3.1 for each of five site characteristics. (Site capacity, the sixth site characteristic previously identified, is not used in calculating the rating.) The site limitation factor is obtained from the second column of the table. The site description factor for each is obtained from the fourth column. The factors in the fourth column correspond to the siting limitation description in the third column. For cooling water availability, site land area, and utility plans, the site description factors are obtained directly from the fourth column. For power transmission land requirements and proximity to metropolitan areas, the site description factors are obtained by performing the operations described in the fourth column. The factor descriptions are designed so that the lowest numerical rating defines the most desirable plant site. 


\section{TABLE 3.1. Site Rating Calculation Data}

Siting

Limitation

Siting

Site

Siting Characteristic

Cooling water avail-

ability

Factor

Limitation Description

Description Factor

10

No Timitation

0

10 Water allocation

2

problem

$10 \quad$ Moderate natural

2

limitation

10 Severe natural

4

limitation

Site land area

5 No limitation

0

5 Marginal limitation

1

5 Major limitation

2

\section{Power transmission}

land requirements

$\begin{array}{r}5 \\ 1 \\ \hline\end{array}$

Proximity to metropolitan areas

2 Number of nearby metropolitan areas

\section{Acres of additional} 1 and required

Multiply 0.01 times acres of additional land required

Determine number of the largest 100 metropolitan areas in the U.S. within 50 miles of site

Utility plans for site

2 Not included in current plans
Included in current plans
0

1

The order in which sites will be selected is determined by the site ratings, with the process carried out separately for each federal energy region. The site with the lowest numerical rating in a specific federal energy region will be selected first. The startup date for that plant is the first startup date for a generic plant in that region as described in the EIA forecast. Subsequent plants are selected in a similar manner except that a delay period is 
used in cases where multiple plants will be located at a specific location. The delay period ensures that a reasonable time is allowed between the construction start dates for co-located plants.

Because all plants at one site will have the same numerical rating, all plants at a multiple-plant location will normally be selected for construction in sequence, once construction of the first plant at that site has commenced. However, if startup of an additional plant is necessary before the end of the delay period at a multiple-plant site, the next most desirable site will be selected, even though it has a higher numerical rating. An additional plant will not be started at a multiple-plant site until after the end of the delay period for the last plant constructed at that site. An exception to this process is the case where no other sites are available within the same federal energy region. In that case, additional plants will be started at the multiple site even though the period between startups is less than the delay period.

\subsubsection{Base Case for Site Selections}

A base case for the generic site selection method is presented in this section to illustrate use of the method and its results. The four types of input information are described first, and, then, the results are presented.

\subsubsection{Input Information}

The four types of required input information are:

1. the forecast startup schedule for the generic power plants

2. a description of each potential site

3. the delay period for multiple plants on a site

4. the relative siting characteristic values.

Each of these information types for the base case is briefly described below.

Generic Plant Startup Schedule. The generic plant startup schedule was obtained from the report by Heeb and Libby (1986) and is presented in Appendix A, Table A.1. The forecast is based on the EIA 1985 forecast of electricity requirements (Gielecki et al. 1985).

Description of The Potential Sites. The descriptions of the potential sites were obtained from reports by Briggs et al. (1978) and Burwell and Lane 
(1980). The descriptions are summarized in Appendix B, Table B.1. The information in the column entitled Excess Capacity is the additional generating capacity (in MWe) that could be built at the site. The information in the column entitled Water Limitation indicates restrictions on water availability. A blank in this column means that no water availability problems exist. The term "Alloc." means that additional water is available but must be obtained by allocation. The term "N-Severe" means that there is a severe natural restriction on water availability. The term "N-Moderate" means there is a moderate natural restriction on availability. For the column entitled Land Needs, a blank space in the column means ample land is available, the term "Marginal" means a marginal amount of land is available on the site for additional plants, and the term "Major" means insufficient land is available on the site for additional plants. However, it is assumed that additional land could be purchased as needed to satisfy site generating capacity requirements. The column entitled Transmission Corridor provides data on the number of additional acres needed for transmission lines. The column entitled Curr. Plan contains the number " 1 " if the site is included in current utility plans for plant operations and a "0" if it is not included in current plans. The column entitled Metro Prox contains data that indicate the number of the 100 largest U.S. metropolitan areas located within 50 miles of the site.

The Delay Period. A two-year delay period was selected for the minimum permissible interval between plant startups at a multiple-plant site.

The Relative Siting Characteristic Values. The values selected for the base case were presented previously in Table 3.1.

3.3.2.2 Base Case Results

The results for the base case are presented in Appendix C, Table C.1.

\subsubsection{The Sensitivity Cases}

An important consideration for spent-fuel logistics analyses are the differences in nuclear plant site selections that could result from changes in forecast electricity requirements or in the relative importance of the site selection limitations. If significant differences in site selections occur 
because of such changes, significant changes in the conclusions for the logis tics analyses could also occur since the forecasts and factor values vary with time.

The sensitivity of the generic site selection to differences in the annual electricity-requirement forecasts, in the delay factor for plant startups at multiple plant sites, and in the relative importance of the site-selection $1 \mathrm{im-}$ itations is described in this section. A separate generic-site forecast was prepared and analyzed for each of six sensitivity cases. Each of these cases is described and analyzed in the following subsections. In each of the sensitivity cases, only one study parameter is varied from the base case.

\subsubsection{Sensitivity to Changes in the Annual Electricity Forecast}

The sensitivity of the generic site selections to changes in the annual electricity forecast was analyzed by comparing the base case, which is based on the current 1985 electricity forecast (Heeb and Libby 1986), to the previous forecast of site selections based on the 1984 electricity requirements (Heeb et al. 1985). All other assumptions were the same as for the base case.

The postulated site selections for this previous forecast are presented in Appendix C, Table C.1, Column 3. Comparison of site selections for this previous forecast with the base case (Table C.1, Column 2) shows that there are differences in the number of sites selected and in the sequence of the selections. More sites are selected for the base case because more plants are needed to satisfy the larger demand for electricity. The differences in the sequence of site selections result from the changes in timing for plant startups. Because the times between the plant startups are shorter for the base case, the required two-year delay factor between startups at multiple-plant sites has a greater effect on the sequence of plant startups.

\subsubsection{Sensitivity to the Delay Factor for Multiple-Power Plant Sites}

The base case has a two-year delay factor because that approximates the most economical scheduling of construction personnel. In this case, a sensitivity analysis was run assuming a delay factor of only one year.

The postulated site selections for this case are presented in Table C.1, Column 4. Comparison of those selections with the base case shows that about 
40 percent of the plant startup dates are changed by varying the delay factor. The same sites are selected in each case. However, the sequence of the site selections changes because the startup dates for the later plants at a multiple plant site are advanced as much as four years.

\subsubsection{Sensitivity to the Cooling-Water Availability Factor}

Cooling-water availability is given very high importance in the base case. As a result, the sites with limited water supplies generally were determined in the base case to be the least desirable sites and, therefore, usually the last sites selected. Any additional increase in the importance of water availability would have changed the site-selection sequence for only one site in only one federal energy region. Consequently, the sensitivity of site selection to water availability was studied by reducing the weight used for cooling water availability by 50 percent.

The postulated site selections for this case are presented in Table C.2, Column 3. Comparison of these results with the base case (repeated in that table) shows only a minor change in the sequence of site selections; the only changes are in Federal Energy Region 9, which includes arid areas of California.

\subsubsection{Sensitivity to the Land-Area Factor}

The availability of sufficient land area is an important discriminator for site selection and was considered to be about one-half as important as the availability of water in the base case. The sensitivity of site selection to land availability was investigated by reducing the land availability factor by 60 percent. This adjustment corresponds to the assumption that relatively little difficulty would be experienced in purchasing additional satisfactory land near existing plants.

The postulated site selections for this case are presented in Table C.2, Column 4. In general, reducing the emphasis on land availability has a small effect on the site-selection sequence. Only 31 percent of the sites changed. These changes resulted because sufficient land is available at most sites for construction of the number of additional power plants that correspond to the maximum site capacity. 


\subsubsection{Sensitivity to the Power-Transmission Factor}

Power transmission is considered one of the least important discriminators for site selection. It generally affects site selection only in those cases where large land areas (i.e., more than 300 acres) are needed for additional power-transmission facilities. The sensitivity of site selection to powertransmission considerations was investigated by doubling the power-transmission factor.

The postulated site selections for this case are presented in Table C.2, Column 5. In general, doubling the transmission factor has a substantial effect on the site-selection sequence. About 45 percent of the sites changed. In several cases the use of specific sites is delayed considerably until after available space has been utilized at sites that require less land for power-transmission facilities.

\subsubsection{Sensitivity to the Metropolitan-Proximity Factor}

The proximity to metropolitan areas is an important discriminator among sites. Public concern about radiation during normal operations and possible accidents is the primary reason for the importance of this factor. The sensitivity of site selection to this factor was investigated by doubling the metropolitan-proximity factor.

The postulated site selections for this case are presented in Table C.2, Column 6. In general, doubling the metropolitan-proximity factor (i.e., doubling the importance) has a substantial effect on the site-selection sequence. About 55 percent of the sites changed. In several cases, startup of plants at specific sites is delayed considerably until after available space has been utilized at sites farther from metropolitan areas. 


\subsection{CONCLUSIONS AND RECOMMENDATIONS}

The EIA forecasts of future nuclear power plant operation do not identify the sites for plants that start operating after the year 2000. A method was developed for predicting the probable sites and startup sequence for those plants. This method has been used to predict the probable sites and startup sequences for the EIA Middle Case, which is used to estimate future U.S. electricity requirements.

The various sites were rated by considering the following site characteristics: cooling water availability, site land area, power transmission land requirements, proximity to metropolitan areas, and utility plans for the sites. A composite numerical rating was developed for each site by use of descriptions of these site characteristics and assignment of a relative value for each. The sequence of power plant startups was then selected on the basis of startups at the best sites before startups at lower-rated sites. Seven cases were studied to determine site selection sequences for future nuclear power plants and the sensitivity of those sequences to changes in the electricity requirements and in the relative values for each of the site rating factors. The general conclusions and recommendations resulting from analysis of those cases are:

1. A change in the electricity requirements may change the sequence in which sites are selected.

Changing the electricity requirements may change the total number of plants forecast to operate and the sequence of plant startups. The number of plants forecast to operate is directly related to the electricity requirements. The sequence of plant startups may change when the forecasts change because of the effect that delay factors have on startups at multiple-plant sites. If more plants are needed because of increases in electricity requirements, the plant startup dates will be closer together. This means that plants at less desirable sites may have to be substituted for plants located at more desirable, multiple-plant sites. 
2. The sequence of site selections is very dependent on the relative values placed on the site-rating factors.

The numerical rating for a site is obtained by multiplying each sitelimitation factor by the appropriate site-description factor and then adding the results. Placing a high or low relative value on a characteristic results in a similar emphasis on that site limitation factor. Care must be exercised when selecting those relative values to prevent inappropriate emphasis on specific factors.

3. Varying the relative values of the siting limitations by as much as 50 percent does not appear to have a significant effect on the sequence in which sites are initially selected.

The initial sites selected have the best characteristics, and, consequently, the most desirable low numerical ratings. Increasing or decreasing the relative value of one site characteristic by as much as 50 percent causes a small change in the total numerical rating for the best sites; this is because, for the best sites, the relative value is multiplied by a small site-description factor. On the other hand, a 50 percent change in a relative value of a characteristic can have a large effect on the sequence of plant startups during the later years of a study. In that case, the relative values are multiplied times a site-description factor with a larger numerical value, and a larger change in the total rating of a site can result.

4. The number of generic sites used in a study should exceed the required number of plants by at least 50 percent and those sites should be a representative sample of the best available sites for current siting conditions.

If the available sites exceed the needed sites by only a small percent, essentially all sites will be selected. Any logistics analyses based on those sites may be biased because the sites considered may not be a representative sample, for current siting conditions, of the best sites in the region being studied. The siting information used for this study was published in the open literature and is representative of the siting 
situation in the 1960s and 1970s. Therefore, the results obtained may not be representative of current conditions.

5. Each siting analysis should include a sensitivity analysis.

The relative values selected for the siting parameters will depend on the judgment and social values of the persons making an analysis and may be quite different from the values selected by others. A sensitivity analysis that uses the probable range of those values will demonstrate the effects of varying the values on the sequence of plant startups and will provide an indication of whether or not it is desirable to study the relative values in greater depth.

The siting method described in this report is based on the selection of each site from all available sites within a federal energy region. Actual future siting decisions made by a number of separate, independently-acting utilities will probably differ in detail, but should produce results that are similar in the aggregate to those presented here. The site-selection information provided in this report should not be interpreted as an exact forecast of the locations and sequences of future plant startups. Use of this information for certain types of analyses (e.g., route-specific transportation assessments) is inappropriate. 


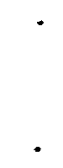




\subsection{REFERENCES}

Briggs, R. B., et a1. 1978. Feasibility of a Nuclear Siting Policy Based on the Expansion of Existing Sites. ORAU/IEA-78-19(R), Institute for Energy AnaTysis, Oak Ridge Associated Universities, Oak Ridge, Tennessee.

Burwel1, C. C. and J. A. Lane. 1980. Nuclear Site Planning to 2025. ORAU/IEA-80-5A(M), Institute for Energy Analysis, Oak Ridge Associated Universities, Oak Ridge, Tennessee.

Gielecki, M. et al. 1985. Commercial Nuclear Power 1985: Prospects for the United States and the World. DOE/EIA-0438 (85), U.S. Department of Energy, Washington, D.C.

Heeb, C. M., R. A. Libby and G. M. Holter. 1985. Reactor-Specific Spent Fuel Discharge Projections: 1984 to 2020. PNL-5396, Pacific Northwest Laboratory, Richland, Washington.

Heeb, C. M., R. A. Libby, R. C. Walling and W. L. Purcell. 1986. ReactorSpecific Spent Fuel Discharge Projections: 1985 to 2020. PNL-5833, Pacific Northwest Laboratory, Richland, Washington.

Rand MCNally and Company. 1983. 1983 Commercial Atlas and Marketing Guide, One Hundred Fourteenth Edition. Chicago, Illinois. 


\section{APPENDIX A}

GENERIC NUCLEAR POWER REACTORS REQUIRED TO MEET OVERALL INSTALLED-CAPACITY PROJECTIONS IN EIA MIDDLE CASE 
TABLE A.1. Generic Nuclear Power Plants Required to Meet Overall Installed-Capacity Projections in EIA Middle Case

\begin{tabular}{|c|c|c|c|c|}
\hline $\begin{array}{c}\text { Reactor } \\
\text { Identification }\end{array}$ & $\begin{array}{l}\text { Federal } \\
\text { Region }\end{array}$ & $\begin{array}{l}\text { Startup } \\
\text { Year } \\
\end{array}$ & $\begin{array}{l}\text { Date } \\
\text { Month } \\
\end{array}$ & $\begin{array}{c}\text { Retirement } \\
\text { Year }\end{array}$ \\
\hline P010101 & 4 & 2001 & 01 & 2041 \\
\hline P010201 & 5 & 2001 & 01 & 2041 \\
\hline B010101 & 2 & 2001 & 01 & 2041 \\
\hline P010305 & 4 & 2001 & 05 & 2041 \\
\hline B010209 & 3 & 2001 & 09 & 2041 \\
\hline P020101 & 3 & 2002 & 01 & 2042 \\
\hline P020201 & 5 & 2002 & 01 & 2042 \\
\hline P020301 & 4 & 2002 & 01 & 2042 \\
\hline B020101 & 9 & 2002 & 01 & 2042 \\
\hline P020403 & 2 & 2002 & 03 & 2042 \\
\hline B020208 & 10 & 2002 & 08 & 2042 \\
\hline P030101 & 9 & 2003 & 01 & 2043 \\
\hline P030201 & 6 & 2003 & 01 & 2043 \\
\hline P030301 & 4 & 2003 & 01 & 2043 \\
\hline B030101 & 4 & 2003 & 01 & 2043 \\
\hline P030403 & 1 & 2003 & 03 & 2043 \\
\hline B030208 & 5 & 2003 & 08 & 2043 \\
\hline P040101 & 5 & 2004 & 01 & 2044 \\
\hline P040201 & 3 & 2004 & 01 & 2044 \\
\hline P040301 & 4 & 2004 & 01 & 2044 \\
\hline B040101 & 6 & 2004 & 01 & 2044 \\
\hline P040402 & 10 & 2004 & 02 & 2044 \\
\hline B040208 & 4 & 2004 & 08 & 2044 \\
\hline P050101 & 5 & 2005 & 01 & 2045 \\
\hline P050201 & 4 & 2005 & 01 & 2045 \\
\hline P050301 & 2 & 2005 & 01 & 2045 \\
\hline P050401 & 9 & 2005 & 01 & 2045 \\
\hline B050101 & 5 & 2005 & 01 & 2045 \\
\hline B050205 & 3 & 2005 & 05 & 2045 \\
\hline P050508 & 3 & 2005 & 08 & 2045 \\
\hline P060101 & 4 & 2006 & 01 & 2046 \\
\hline P060201 & 7 & 2006 & 01 & 2046 \\
\hline P060301 & 5 & 2006 & 01 & 2046 \\
\hline B060101 & 4 & 2006 & 01 & 2046 \\
\hline B060202 & 7 & 2006 & 02 & 2046 \\
\hline P060405 & 6 & 2006 & 05 & 2046 \\
\hline P070101 & 4 & 2007 & 01 & 2047 \\
\hline P070201 & 1 & 2007 & 01 & 2047 \\
\hline P070301 & 5 & 2007 & 01 & 2047 \\
\hline P070401 & 4 & 2007 & 01 & 2047 \\
\hline P070501 & 3 & 2007 & 01 & 2047 \\
\hline B070101 & 2 & 2007 & 01 & 2047 \\
\hline
\end{tabular}


TABLE A.1. (contd)

\begin{tabular}{|c|c|c|c|c|}
\hline $\begin{array}{c}\text { Reactor } \\
\text { Identification }\end{array}$ & $\begin{array}{l}\text { Federa } 1 \\
\text { Region } \\
\end{array}$ & $\begin{array}{l}\text { Startup } \\
\text { Year }\end{array}$ & $\begin{array}{l}\text { Date } \\
\text { Month }\end{array}$ & $\begin{array}{c}\text { Retirement } \\
\text { Year }\end{array}$ \\
\hline B070201 & 9 & 2007 & 01 & 2047 \\
\hline B070307 & 4 & 2007 & 07 & 2047 \\
\hline P070612 & 2 & 2007 & 12 & 2047 \\
\hline P080101 & 9 & 2008 & 01 & 2048 \\
\hline P080201 & 4 & 2008 & 01 & 2048 \\
\hline P080301 & 5 & 2008 & 01 & 2048 \\
\hline P080401 & 10 & 2008 & 01 & 2048 \\
\hline P080501 & 4 & 2008 & 01 & 2048 \\
\hline P080601 & 6 & 2008 & 01 & 2048 \\
\hline P080701 & 5 & 2008 & 01 & 2048 \\
\hline B080101 & 5 & 2008 & 01 & 2048 \\
\hline B080201 & 1 & 2008 & 01 & 2048 \\
\hline B080301 & 4 & 2008 & 01 & 2048 \\
\hline B080406 & 3 & 2008 & 06 & 2048 \\
\hline P080809 & 3 & 2008 & 09 & 2048 \\
\hline P090101 & 4 & 2009 & 01 & 2049 \\
\hline P090201 & 1 & 2009 & 01 & 2049 \\
\hline P090301 & 4 & 2009 & 01 & 2049 \\
\hline P090401 & 5 & 2009 & 01 & 2049 \\
\hline P090501 & 2 & 2009 & 01 & 2049 \\
\hline P090601 & 9 & 2009 & 01 & 2049 \\
\hline P090701 & 3 & 2009 & 01 & 2049 \\
\hline P090801 & 4 & 2009 & 01 & 2049 \\
\hline P090901 & 7 & 2009 & 01 & 2049 \\
\hline P091001 & 5 & 2009 & 01 & 2049 \\
\hline B090101 & 5 & 2009 & 01 & 2049 \\
\hline B090201 & 6 & 2009 & 01 & 2049 \\
\hline B090301 & 4 & 2009 & 01 & 2049 \\
\hline B090401 & 10 & 2009 & 01 & 2049 \\
\hline B090501 & 5 & 2009 & 01 & 2049 \\
\hline P091108 & 4 & 2009 & 08 & 2049 \\
\hline B090611 & 4 & 2009 & 11 & 2049 \\
\hline P100101 & 6 & 2010 & 01 & 2050 \\
\hline P100201 & 5 & 2010 & 01 & 2050 \\
\hline P100301 & 4 & 2010 & 01 & 2050 \\
\hline P100401 & 1 & 2010 & 01 & 2050 \\
\hline P100501 & 2 & 2010 & 01 & 2050 \\
\hline P100601 & 4 & 2010 & 01 & 2050 \\
\hline B100101 & 2 & 2010 & 01 & 2050 \\
\hline B100201 & 9 & 2010 & 01 & 2050 \\
\hline B100302 & 3 & 2010 & 02 & 2050 \\
\hline P100705 & 9 & 2010 & 05 & 2050 \\
\hline P110101 & 10 & 2011 & 01 & 2051 \\
\hline P110201 & 4 & 2011 & 01 & 2051 \\
\hline P110301 & 5 & 2011 & 01 & 2051 \\
\hline
\end{tabular}


TABLE A.1. (contd)

\begin{tabular}{|c|c|c|c|c|}
\hline $\begin{array}{c}\text { Reactor } \\
\text { Identification }\end{array}$ & $\begin{array}{l}\text { Federal } \\
\text { Region }\end{array}$ & $\begin{array}{l}\text { Startup } \\
\text { Year }\end{array}$ & $\begin{array}{l}\text { Date } \\
\text { Month }\end{array}$ & $\begin{array}{l}\text { Retirement } \\
\quad \text { Year } \\
\end{array}$ \\
\hline P110401 & 4 & 2011 & 01 & 2051 \\
\hline P110501 & 3 & 2011 & 01 & 2051 \\
\hline P110601 & 5 & 2011 & 01 & 2051 \\
\hline P110701 & 6 & 2011 & 01 & 2051 \\
\hline B110101 & 4 & 2011 & 01 & 2051 \\
\hline B110201 & 5 & 2011 & 01 & 2051 \\
\hline B110301 & 1 & 2011 & 01 & 2051 \\
\hline B110406 & 4 & 2011 & 06 & 2051 \\
\hline P110812 & 4 & 2011 & 12 & 2051 \\
\hline P120101 & 2 & 2012 & 01 & 2052 \\
\hline P120201 & 9 & 2012 & 01 & 2052 \\
\hline P120301 & 4 & 2012 & 01 & 2052 \\
\hline P120401 & 5 & 2012 & 01 & 2052 \\
\hline B120101 & 6 & 2012 & 01 & 2052 \\
\hline B120201 & 5 & 2012 & 01 & 2052 \\
\hline P120503 & 1 & 2012 & 03 & 2052 \\
\hline B120308 & 3 & 2012 & 08 & 2052 \\
\hline P130101 & 3 & 2013 & 01 & 2053 \\
\hline P130201 & 4 & 2013 & 01 & 2053 \\
\hline P130301 & 7 & 2013 & 01 & 2053 \\
\hline P130401 & 5 & 2013 & 01 & 2053 \\
\hline P130501 & 10 & 2013 & 01 & 2053 \\
\hline P130601 & 4 & 2013 & 01 & 2053 \\
\hline B130101 & 4 & 2013 & 01 & 2053 \\
\hline B130201 & 7 & 2013 & 01 & 2053 \\
\hline B130301 & 2 & 2013 & 01 & 2053 \\
\hline P130702 & 6 & 2013 & 02 & 2053 \\
\hline P140101 & 2 & 2014 & 01 & 2054 \\
\hline P140201 & 9 & 2014 & 01 & 2054 \\
\hline P140301 & 4 & 2014 & 01 & 2054 \\
\hline P140401 & 5 & 2014 & 01 & 2054 \\
\hline B140101 & 9 & 2014 & 01 & 2054 \\
\hline B140201 & 4 & 2014 & 01 & 2054 \\
\hline P140505 & 3 & 2014 & 05 & 2054 \\
\hline B140308 & 5 & 2014 & 08 & 2054 \\
\hline P150101 & 4 & 2015 & 01 & 2055 \\
\hline P150201 & 1 & 2015 & 01 & 2055 \\
\hline P150301 & 5 & 2015 & 01 & 2055 \\
\hline P150401 & 5 & 2015 & 01 & 2055 \\
\hline P150501 & 4 & 2015 & 01 & 2055 \\
\hline B150101 & 10 & 2015 & 01 & 2055 \\
\hline B150201 & 4 & 2015 & 01 & 2055 \\
\hline P150608 & 3 & 2015 & 08 & 2055 \\
\hline B150311 & 3 & 2015 & 11 & 2055 \\
\hline P160101 & 5 & 2016 & 01 & 2056 \\
\hline
\end{tabular}




\begin{tabular}{|c|c|c|c|c|}
\hline $\begin{array}{c}\text { Reactor } \\
\text { Identification }\end{array}$ & $\begin{array}{l}\text { Federal } \\
\text { Region } \\
\end{array}$ & $\begin{array}{l}\text { Startup } \\
\text { Year } \\
\end{array}$ & $\begin{array}{l}\text { Date } \\
\text { Month } \\
\end{array}$ & $\begin{array}{c}\text { Ret i rement } \\
\text { Year } \\
\end{array}$ \\
\hline P160201 & 4 & 2016 & 01 & 2056 \\
\hline P160301 & 2 & 2016 & 01 & 2056 \\
\hline P160401 & 9 & 2016 & 01 & 2056 \\
\hline P160501 & 6 & 2016 & 01 & 2056 \\
\hline B160101 & 5 & 2016 & 01 & 2056 \\
\hline B160201 & 1 & 2016 & 01 & 2056 \\
\hline P160606 & 4 & 2016 & 06 & 2056 \\
\hline 8160309 & 4 & 2016 & 09 & 2056 \\
\hline P170101 & 10 & 2017 & 01 & 2057 \\
\hline P170201 & 5 & 2017 & 01 & 2057 \\
\hline P170301 & 3 & 2017 & 01 & 2057 \\
\hline B170101 & 6 & 2017 & 01 & 2057 \\
\hline P170407 & 4 & 2017 & 07 & 2057 \\
\hline B170211 & 2 & 2017 & 11 & 2057 \\
\hline P180101 & 7 & 2018 & 01 & 2058 \\
\hline P180201 & 1 & 2018 & 01 & 2058 \\
\hline P180301 & 5 & 2018 & 01 & 2058 \\
\hline P180401 & 4 & 2018 & 01 & 2058 \\
\hline P180501 & 2 & 2018 & 01 & 2058 \\
\hline B180101 & 9 & 2018 & 01 & 2058 \\
\hline B180201 & 4 & 2018 & 01 & 2058 \\
\hline P180605 & 9 & 2018 & 05 & 2058 \\
\hline B180308 & 5 & 2018 & 08 & 2058 \\
\hline P190101 & 4 & 2019 & 01 & 2059 \\
\hline P190201 & 6 & 2019 & 01 & 2059 \\
\hline P190301 & 5 & 2019 & 01 & 2059 \\
\hline P190406 & 3 & 2019 & 01 & 2059 \\
\hline B190101 & 3 & 2019 & 01 & 2059 \\
\hline B190209 & 4 & 2019 & 09 & 2059 \\
\hline B200101 & 5 & 2020 & 01 & 2060 \\
\hline P200101 & 4 & 2020 & 01 & 2060 \\
\hline P200201 & 5 & 2020 & 01 & 2060 \\
\hline P200301 & 4 & 2020 & 01 & 2060 \\
\hline P200407 & 1 & 2020 & 07 & 2060 \\
\hline B200211 & 4 & 2020 & 11 & 2060 \\
\hline
\end{tabular}

Source: Heeb et a1. 1986. 
APPENDIX B

EXISTING AND PROSPECTIVE SITES FOR NUCLEAR POWER PLANTS 

TABLE B.1. Existing and Prospective Sites for Nuclear Power Plants

\begin{tabular}{|c|c|c|c|c|c|c|c|c|c|c|c|c|c|c|c|c|c|}
\hline & Site & Site Nane & $\begin{array}{l}\text { Fed. } \\
\text { Reg. }\end{array}$ & $\begin{array}{l}\text { Assuaed } \\
\text { Site } \\
\text { Capacity } \\
\text { (Life) (a) }\end{array}$ & Long: & Lat. & $\begin{array}{c}\text { EIA } \\
\text { Rez } \\
\text { No. }\end{array}$ & $\begin{array}{l}\text { lidcase } \\
\text { ctors } \\
\text { Cap (Mile) }\end{array}$ & $\begin{array}{r}\text { Excess } \\
\text { Capacit } \\
\text { Cap. (Mile) }\end{array}$ & units & $\begin{array}{l}\text { Water } \\
\text { Linitations }\end{array}$ & $\begin{array}{l}\text { Land } \\
5 \text { Needs }\end{array}$ & $\begin{array}{c}\begin{array}{r}\text { Trans } \\
\text { Corrido }\end{array} \\
\text { Needs }\end{array}$ & $\begin{array}{l}\text { sission } \\
\text { or (acre. } \\
\text { lunit }\end{array}$ & $\begin{array}{l}\text { s) } \\
\text { Curr. } \\
\text { Plan }\end{array}$ & $\begin{array}{l}\text { Metro } \\
\text { Prox. }\end{array}$ & Rating \\
\hline$\stackrel{\infty}{\infty}$ & $\begin{array}{l}\text { CT-1 } \\
\text { CT-2 } \\
M A-1 \\
M A-2 \\
\text { MA-3 } \\
\text { ME-1 } \\
\text { ME-2 } \\
\text { NH-1 } \\
\text { RI-1 } \\
\text { VI-1 } \\
\text { NJ-1 } \\
\text { NJ-2 } \\
\text { NJ-4 } \\
\text { NY-1 } \\
\text { NY-2 } \\
\text { NY-3 } \\
\text { MY-4 } \\
\text { NY-5 } \\
\text { MY-6 } \\
\text { NY-7 } \\
\text { MD-1 } \\
\text { MD-2 } \\
\text { PA-1 } \\
\text { PA-2 } \\
\text { PA-3 } \\
\text { PA-4 } \\
\text { PA-5 } \\
\text { PA-7 } \\
\text { PA-8 } \\
\text { PA-9 } \\
\text { VA-1 } \\
\text { VA-2 }\end{array}$ & $\begin{array}{l}\text { Conn. Yankee } \\
\text { Millstone } \\
\text { Yankee Rowe } \\
\text { Pilgrin } \\
\text { Montague } \\
\text { Maine Yankee } \\
\text { Richnond } \\
\text { Seabrook } \\
\text { MEPCo (Charlestown) } \\
\text { Vernont Yankee } \\
\text { Oyster Cr./Forked R. } \\
\text { Salea/Hope Creek } \\
\text { Atlantic } \\
\text { Indian Point } \\
\text { Nino Mile Pt./Fitz. } \\
\text { Shorehan } \\
\text { Cinna } \\
\text { Greene County } \\
\text { Jamesport } \\
\text { Sterling } \\
\text { Calvert Cliffs } \\
\text { Douglas Point } \\
\text { Peach Botton } \\
\text { Linerick } \\
\text { Shipp./Beaver Valley } \\
\text { Three Mile Island } \\
\text { Susquehanna } \\
\text { Lock Haven } \\
\text { Towanda } \\
\text { Tionesta } \\
\text { Surry } \\
\text { North Anna }\end{array}$ & $\begin{array}{l}1 \\
1 \\
1 \\
1 \\
1 \\
1 \\
1 \\
1 \\
1 \\
1 \\
2 \\
2 \\
2 \\
2 \\
2 \\
2 \\
2 \\
2 \\
2 \\
2 \\
3 \\
3 \\
3 \\
3 \\
3 \\
3 \\
3 \\
3 \\
3 \\
3 \\
3 \\
3\end{array}$ & 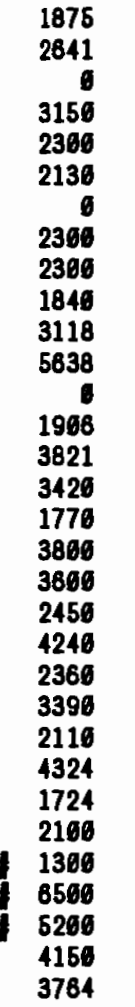 & $\begin{array}{l}72.30 \\
72.16 \\
72.56 \\
76.35 \\
69.42 \\
70.61 \\
72.31 \\
74.12 \\
76.32 \\
73.57 \\
76.26 \\
72.52 \\
77.19\end{array}$ & $\begin{array}{l}41.39 \\
41.19 \\
42.44 \\
41.57 \\
43.57 \\
42.54 \\
42.47 \\
39.49 \\
39.28 \\
41.16 \\
43.27 \\
40.58 \\
43.17\end{array}$ & $\begin{array}{l}1 \\
3 \\
1 \\
1 \\
1 \\
2 \\
1 \\
1 \\
3 \\
3 \\
3 \\
1 \\
1\end{array}$ & $\begin{array}{r}582 \\
2888 \\
175 \\
855 \\
825 \\
2396 \\
\\
514 \\
650 \\
3272 \\
2163 \\
2521 \\
826 \\
470\end{array}$ & 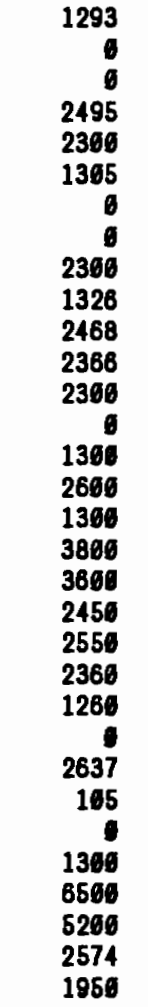 & $\begin{array}{l}2 \\
6 \\
1 \\
2 \\
1 \\
3 \\
3 \\
2 \\
2 \\
2 \\
1 \\
2 \\
2 \\
6 \\
1 \\
6 \\
5 \\
2 \\
2\end{array}$ & Alloc. & $\begin{array}{l}\text { Marginal } \\
\text { Marginal }\end{array}$ & $\begin{array}{r}96 \\
336 \\
1190 \\
330 \\
\\
450 \\
\\
1600 \\
6000 \\
5060\end{array}$ & $\begin{array}{l}225 \\
1606 \\
1660 \\
1006\end{array}$ & $\begin{array}{l}1 \\
1 \\
1 \\
1 \\
0 \\
1 \\
0 \\
1 \\
0 \\
1 \\
1 \\
1 \\
0 \\
1 \\
1 \\
1 \\
1 \\
0 \\
0 \\
0 \\
1 \\
0 \\
1 \\
1 \\
1 \\
1 \\
1 \\
0 \\
0 \\
0 \\
1 \\
1\end{array}$ & $\begin{array}{l}3 \\
3 \\
6 \\
4 \\
1 \\
6 \\
6 \\
1 \\
1 \\
6 \\
8 \\
2 \\
1 \\
5 \\
2 \\
4 \\
1 \\
1 \\
4 \\
2 \\
2 \\
2 \\
1 \\
3 \\
2 \\
1 \\
2 \\
6 \\
1 \\
6 \\
1 \\
2\end{array}$ & 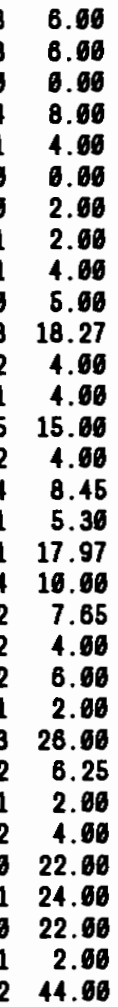 \\
\hline
\end{tabular}


TABLE B.1. (contd)

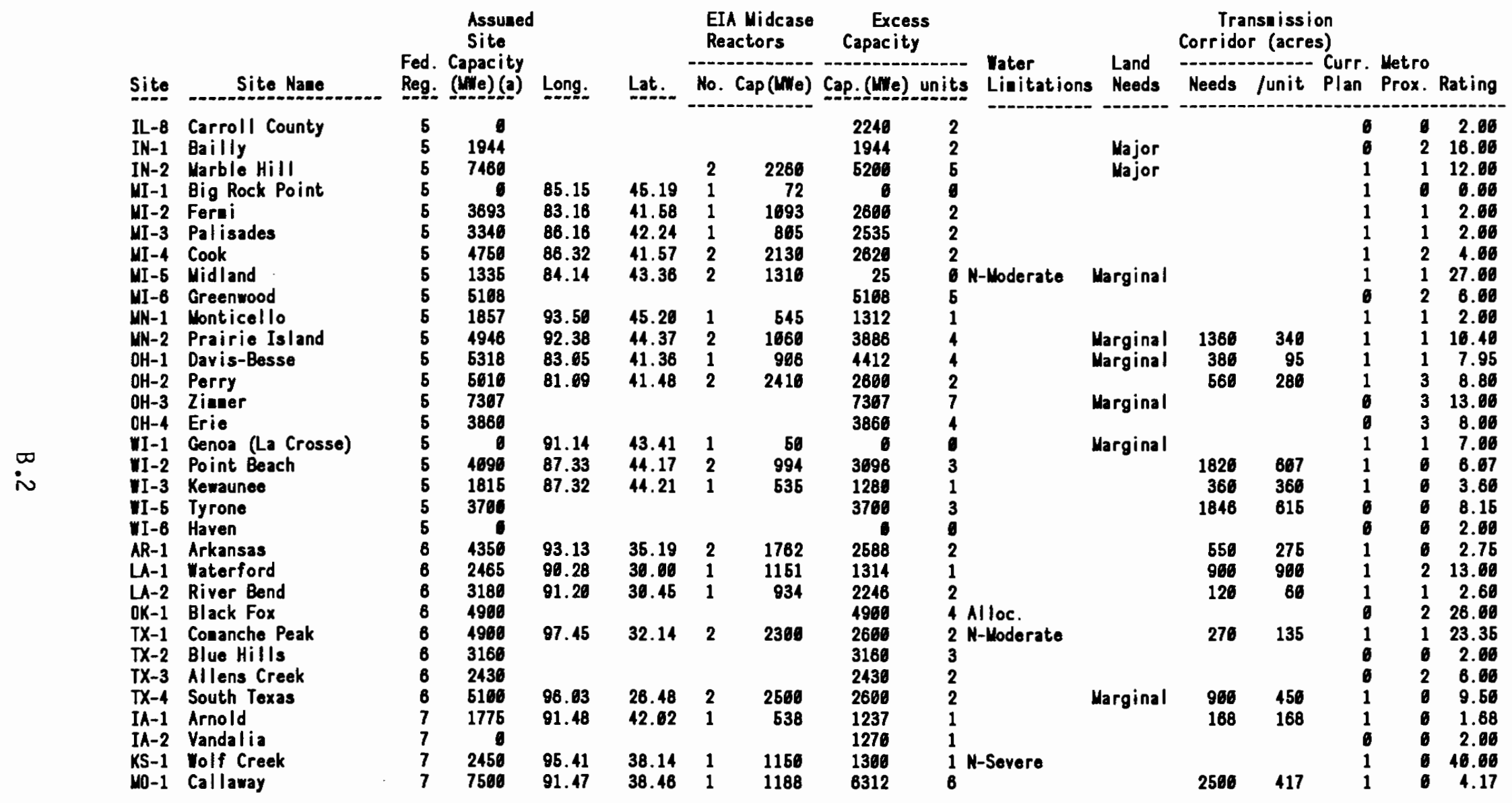


TABLE B.1. (contd)

\begin{tabular}{|c|c|c|c|c|c|c|c|c|c|c|c|c|c|c|c|c|}
\hline Site & Site Nane & $\begin{array}{l}\text { Fed. } \\
\text { Reg. }\end{array}$ & $\begin{array}{l}\text { Assuged } \\
\text { Site } \\
\text { Capacity } \\
\text { (Wile) (a) }\end{array}$ & Long: & Lat. & \begin{tabular}{c} 
EIA \\
Rea \\
\hdashline No.
\end{tabular} & $\begin{array}{l}\text { didease } \\
\text { actors } \\
\text { Cap (Mile) }\end{array}$ & $\begin{array}{c}\text { Excess } \\
\text { Capacity } \\
\text { Cap. (Mile) }\end{array}$ & units & $\begin{array}{l}\text { Water } \\
\text { Limitations }\end{array}$ & $\begin{array}{l}\text { Land } \\
5 \text { Meeds }\end{array}$ & $\begin{array}{c}\text { Trans } \\
\text { Corridor } \\
\text { Needs }\end{array}$ & $\begin{array}{l}\text { ission } \\
\text { r (acres } \\
\text { Junit }\end{array}$ & $\begin{array}{l}\text { S) } \\
\text { Curr. } \\
\text { Plan }\end{array}$ & $\begin{array}{l}\text { Metro } \\
\text { Prox. }\end{array}$ & - Rating \\
\hline $\begin{array}{l}N L-1 \\
N L-2 \\
N L-3 \\
N-4 \\
\text { FL-1 } \\
\text { FL-2 } \\
\text { FL-3 } \\
\text { GA-1 } \\
\text { GA-2 } \\
\text { US-1 } \\
\text { US-2 } \\
N C-1 \\
N C-2 \\
N C-3 \\
N C-4 \\
\text { SC-1 } \\
\text { SC-2 } \\
\text { SC-3 } \\
\text { SC-4 } \\
\text { SC-5 } \\
\text { TN-1 } \\
\text { TH-2 } \\
\text { TN-3 } \\
\text { TN-4 } \\
\text { TN-5 } \\
\text { IL-1 } \\
\text { IL-2 } \\
\text { IL-3 } \\
\text { IL-4 } \\
\text { IL-5 } \\
\text { IL-6 } \\
I L-7\end{array}$ & $\begin{array}{l}\text { Browns Ferry } \\
\text { Farley } \\
\text { Barton } \\
\text { Bellefonte } \\
\text { Turkey Point } \\
\text { Crystal River } \\
\text { St. Lucio } \\
\text { Hatch } \\
\text { Vogtle } \\
\text { Grand Gulf } \\
\text { Yallow Creek } \\
\text { Brunswick } \\
\text { McGuiro } \\
\text { Harris } \\
\text { Perkins } \\
\text { Robinson } \\
\text { Oconee } \\
\text { Sunner } \\
\text { Catawba } \\
\text { Cherokee } \\
\text { Sequoyah } \\
\text { Watts Bar } \\
\text { Clinch River } \\
\text { Hartsville } \\
\text { Phipps Bend } \\
\text { Dresden } \\
\text { Zion } \\
\text { Quad Cities } \\
\text { LaSalle } \\
\text { Byron } \\
\text { Braidwood } \\
\text { Clinton }\end{array}$ & $\begin{array}{l}4 \\
4 \\
4 \\
4 \\
4 \\
4 \\
4 \\
4 \\
4 \\
4 \\
4 \\
4 \\
4 \\
4 \\
4 \\
4 \\
4 \\
4 \\
4 \\
4 \\
4 \\
4 \\
4 \\
5 \\
5 \\
5 \\
5 \\
5 \\
5 \\
5\end{array}$ & 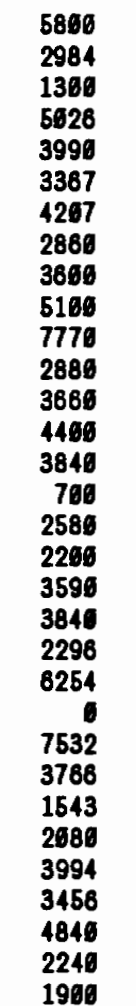 & $\begin{array}{l}87.35 \\
85.66 \\
85.56 \\
86.26 \\
82.42 \\
86.15 \\
82.21 \\
81.46 \\
91.63 \\
88.13 \\
78.61 \\
86.57 \\
78.65 \\
80.16 \\
82.54 \\
81.19 \\
81.64 \\
85.65 \\
84.52 \\
88.65 \\
88.17 \\
87.48 \\
99.19 \\
88.46 \\
89.17 \\
88.13 \\
88.56\end{array}$ & $\begin{array}{l}34.35 \\
31.13 \\
34.43 \\
25.28 \\
28.57 \\
27.21 \\
31.56 \\
33.69 \\
32.69 \\
34.67 \\
33.58 \\
35.26 \\
35.35 \\
43.24 \\
34.48 \\
34.18 \\
35.63 \\
35.14 \\
35.41 \\
36.21 \\
41.24 \\
42.27 \\
41.44 \\
41.15 \\
42.65 \\
41.15 \\
49.16\end{array}$ & $\begin{array}{l}3 \\
2 \\
2 \\
2 \\
1 \\
2 \\
2 \\
2 \\
2 \\
6 \\
2 \\
2 \\
1 \\
1 \\
3 \\
1 \\
2 \\
2 \\
2 \\
\\
6 \\
3 \\
2 \\
2 \\
2 \\
2 \\
2 \\
1\end{array}$ & $\begin{array}{r}3195 \\
1658 \\
\\
2470 \\
1386 \\
825 \\
1634 \\
1561 \\
2426 \\
2590 \\
9 \\
1642 \\
2360 \\
915 \\
760 \\
7661 \\
906 \\
2296 \\
\\
2296 \\
2336 \\
\\
6 \\
1588 \\
2686 \\
1578 \\
2156 \\
2246 \\
2246 \\
450\end{array}$ & $\begin{array}{r}2695 \\
1326 \\
4636 \\
2556 \\
2694 \\
2542 \\
2573 \\
1299 \\
1189 \\
2606 \\
7776 \\
1238 \\
1360 \\
3485 \\
3640 \\
6 \\
6 \\
1396 \\
1396 \\
3840 \\
9 \\
3924 \\
6 \\
7532 \\
3766 \\
\theta \\
2416 \\
1360 \\
2606 \\
9 \\
958\end{array}$ & $\begin{array}{l}2 \\
1 \\
1 \\
2 \\
2 \\
2 \\
2 \\
1 \\
1 \\
2 \\
7 \\
1 \\
1 \\
3 \\
3 \\
6 \\
6 \\
1 \\
1 \\
3 \\
6 \\
4 \\
6 \\
7 \\
3 \\
6 \\
0 \\
2 \\
1 \\
2 \\
0 \\
1 \\
1\end{array}$ & N-Sevoro & Marginal & $\begin{array}{r}1240 \\
321 \\
\\
818 \\
900 \\
360 \\
500 \\
60 \\
\\
730 \\
1200\end{array}$ & $\begin{array}{r}620 \\
321 \\
\\
409 \\
450 \\
180 \\
250 \\
60 \\
\\
365 \\
171\end{array}$ & $\begin{array}{l}1 \\
1 \\
0 \\
1 \\
1 \\
1 \\
1 \\
1 \\
1 \\
1 \\
0 \\
1 \\
1 \\
1 \\
0 \\
1 \\
1 \\
1 \\
1 \\
0 \\
1 \\
1 \\
0 \\
6 \\
0 \\
1 \\
1 \\
1 \\
1 \\
1 \\
1 \\
1\end{array}$ & $\begin{array}{l}0 \\
6 \\
6 \\
1 \\
2 \\
6 \\
1 \\
6 \\
6 \\
0 \\
6 \\
6 \\
2 \\
1 \\
0 \\
6 \\
1 \\
6 \\
2 \\
1 \\
1 \\
1 \\
0 \\
1 \\
1 \\
2 \\
2 \\
1 \\
6 \\
0 \\
6 \\
0\end{array}$ & 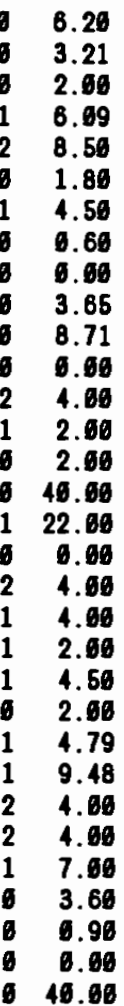 \\
\hline
\end{tabular}


TABLE B.1. (contd)

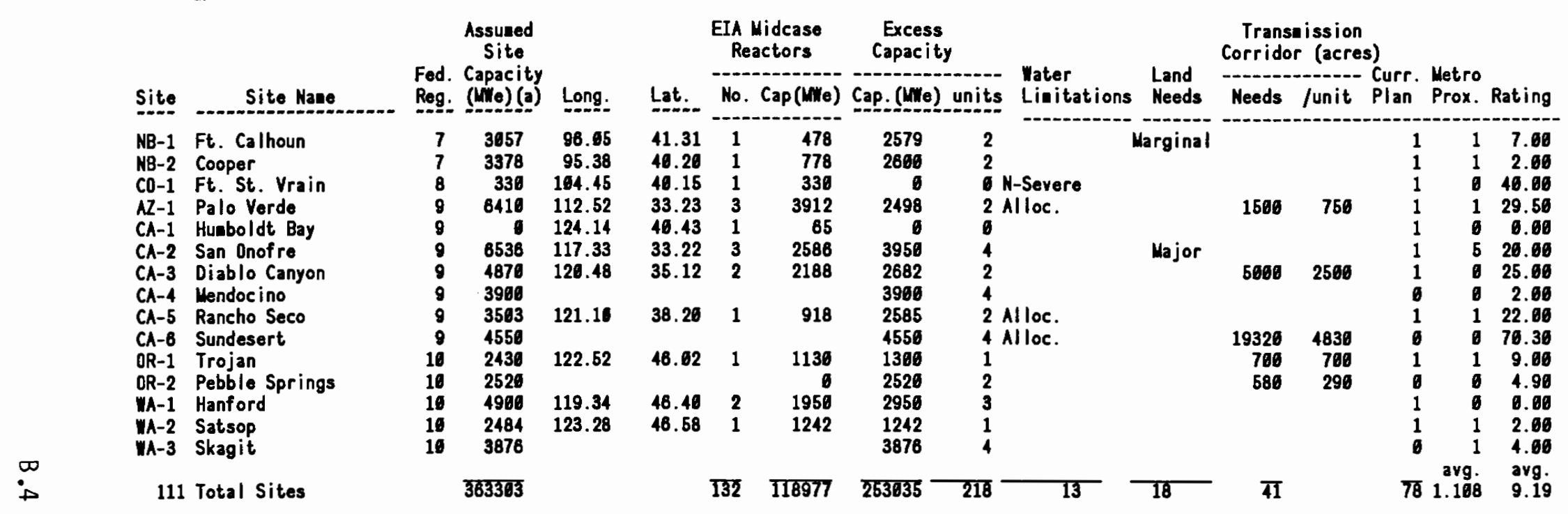

(a) Briggs, R.B., et al. 1978. Feasibility of a Nuclear Siting Policy Based on the Expansion of Existing Sites.

ORAU/IEA-78-19(R), Institute for Energy Analysis, Oak Ridge Associated Universities, Oak Ridge, Tennessee. 


\section{APPENDIX C}

POSTULATED ASSIGNMENTS OF GENERIC REACTORS TO POTENTIAL SITES 
TABLE C.1. Postulated Sequence of Generic Plant Assignments to Potential Sites (General Sensitivity Cases)

\begin{tabular}{|c|c|c|c|c|}
\hline \multirow[t]{2}{*}{$\begin{array}{l}\text { Federal } \\
\text { Reglon } \\
\end{array}$} & \multicolumn{2}{|c|}{$\begin{array}{c}\text { Base Case } \\
\text { (1985 Forecast) }\end{array}$} & \multicolumn{2}{|c|}{$\begin{array}{c}\text { Previous Forecast } \\
(1984 \text { Forecast) }\end{array}$} \\
\hline & $\begin{array}{l}\text { Date } \\
\text { sited }\end{array}$ & site & $\begin{array}{l}\text { Date } \\
\text { Sited }\end{array}$ & site \\
\hline $\begin{array}{l}1 \\
1 \\
1 \\
1 \\
1 \\
1 \\
1 \\
1 \\
1 \\
2(a)\end{array}$ & $\begin{array}{l}2003 / 03 \\
2007 / 01 \\
2008 / 01 \\
2009 / 01 \\
2010 / 01 \\
2011 / 01 \\
2012 / 03 \\
2016 / 01 \\
2018 / 01 \\
2020 / 07\end{array}$ & $\begin{array}{l}\text { Malne Yankee } \\
\text { Montague } \\
\text { NEPCO (Charlestown) } \\
\text { Montague } \\
\text { NEPCO (Charlestown) } \\
\text { Vermont Yankee } \\
\text { Connectl cut Yankee } \\
\text { Pilgrim } \\
\text { PIIgrim } \\
\text { Greene County }\end{array}$ & $\begin{array}{l}2003 / 01 \\
2006 / 05 \\
2008 / 01 \\
2009 / 01 \\
2009 / 01 \\
2010 / 01 \\
2012 / 01 \\
2014 / 01 \\
2017 / 10\end{array}$ & $\begin{array}{l}\text { Malne Yankee } \\
\text { Montague } \\
\text { NEPCO (Charlestown) } \\
\text { Montague } \\
\text { Vermont Yankee (b) } \\
\text { NEPCO (Charlestown) (b) } \\
\text { Connectlcut Yankee } \\
\text { Pligrim } \\
\text { Pligrim }\end{array}$ \\
\hline $\begin{array}{l}2 \\
2 \\
2 \\
2 \\
2 \\
2 \\
2 \\
2 \\
2 \\
2 \\
2 \\
2 \\
2 \\
2\end{array}$ & $\begin{array}{l}2001 / 01 \\
2002 / 03 \\
2005 / 01 \\
2007 / 01 \\
2007 / 12 \\
2009 / 01 \\
2010 / 01 \\
2010 / 01 \\
2012 / 01 \\
2013 / 01 \\
2014 / 01 \\
2016 / 01 \\
2017 / 11 \\
2018 / 01\end{array}$ & $\begin{array}{l}\text { Salem/Hope Creek } \\
\text { Atlantlc } \\
\text { Salem/Hope Creek } \\
\text { Atlantlic } \\
\text { Nine Mile Pt./Fitz. } \\
\text { Ginna } \\
\text { Sterling } \\
\text { Shoreham } \\
\text { Sterling } \\
\text { Shoreham } \\
\text { Jamesport } \\
\text { Jamesport } \\
\text { Greene County } \\
\text { Jamesport }\end{array}$ & $\begin{array}{l}2002 / 01 \\
2004 / 01 \\
2007 / 01 \\
2008 / 01 \\
2009 / 01 \\
2009 / 01 \\
2011 / 01 \\
2012 / 01 \\
2013 / 03 \\
2015 / 03 \\
2018 / 06\end{array}$ & $\begin{array}{l}\text { Salem/Hope Creek } \\
\text { Salem/Hope Creek (b) } \\
\text { NIne Mife Pt./Fitz. }{ }^{\text {(b) }} \\
\text { Ginna (b) } \\
\text { Sterling(b) } \\
\text { Shoreham (b) } \\
\text { Sterling } \\
\text { Shoreham } \\
\text { Jamesport (b) } \\
\text { Jamesport (b) } \\
\text { Jamesport }\end{array}$ \\
\hline $\begin{array}{l}\text { a) } P \\
\text { b) }\end{array}$ & uilt & fference sequeno & the & $\begin{array}{l}\text { on } 1 . \\
\text { ase. }\end{array}$ \\
\hline
\end{tabular}

General Sensitivity Cases

\begin{tabular}{|c|c|}
\hline & $\begin{array}{c}\text { One Year } \\
\text { Delay Factor }\end{array}$ \\
\hline $\begin{array}{l}\text { Date } \\
\text { Sited }\end{array}$ & site \\
\hline $\begin{array}{l}2003 / 03 \\
2007 / 01 \\
2008 / 01 \\
2009 / 01\end{array}$ & $\begin{array}{l}\text { Maine Yankee } \\
\text { Montague (b) } \\
\text { Montague } \\
\text { NEPCO (Charlestown) (b) }\end{array}$ \\
\hline $\begin{array}{l}2010 / 01 \\
2011 / 01 \\
2012 / 03 \\
2016 / 01 \\
2018 / 01 \\
2020 / 07\end{array}$ & $\begin{array}{l}\text { NEPCO (Charlestown) } \\
\text { Vermont Yankee } \\
\text { Connectl cut Yankee } \\
\text { Pligrim } \\
\text { PIlgrim } \\
\text { Greene County }\end{array}$ \\
\hline $\begin{array}{l}2001 / 01 \\
2002 / 03 \\
2005 / 01 \\
2007 / 01 \\
2007 / 12 \\
2009 / 01\end{array}$ & $\begin{array}{l}\text { Salem/Hope Creek } \\
\text { Salem/Hopg, Creek (b) } \\
\text { Atlantic } \\
\text { Atlantic } \\
\text { NIne Mlle Pt./Fitz. } \\
\text { Ginna }\end{array}$ \\
\hline $\begin{array}{l}2010 / 01 \\
2010 / 01 \\
2012 / 01 \\
2013 / 01\end{array}$ & $\begin{array}{l}\text { Sterling } \\
\text { Shoreham } \\
\text { Sterling } \\
\text { Shoreham }\end{array}$ \\
\hline $\begin{array}{l}2014 / 01 \\
2016 / 01 \\
2017 / 11 \\
2018 / 01\end{array}$ & $\begin{array}{l}\text { Jamesport } \\
\text { Jamesport (b) } \\
\text { Jamesport } \\
\text { Greene County }(b)\end{array}$ \\
\hline
\end{tabular}


TABLE C.1. (contd)

General Sensitivity Cases

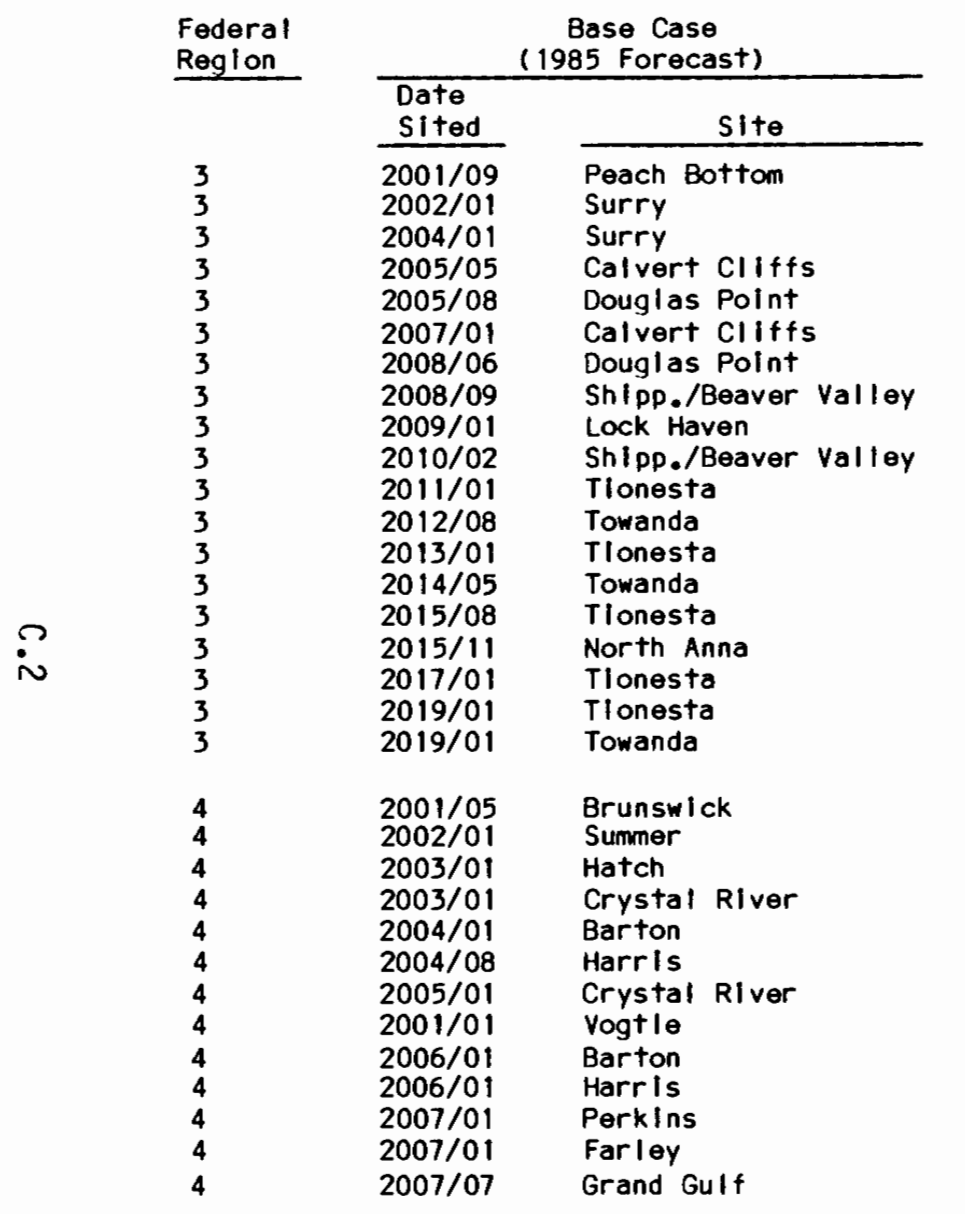

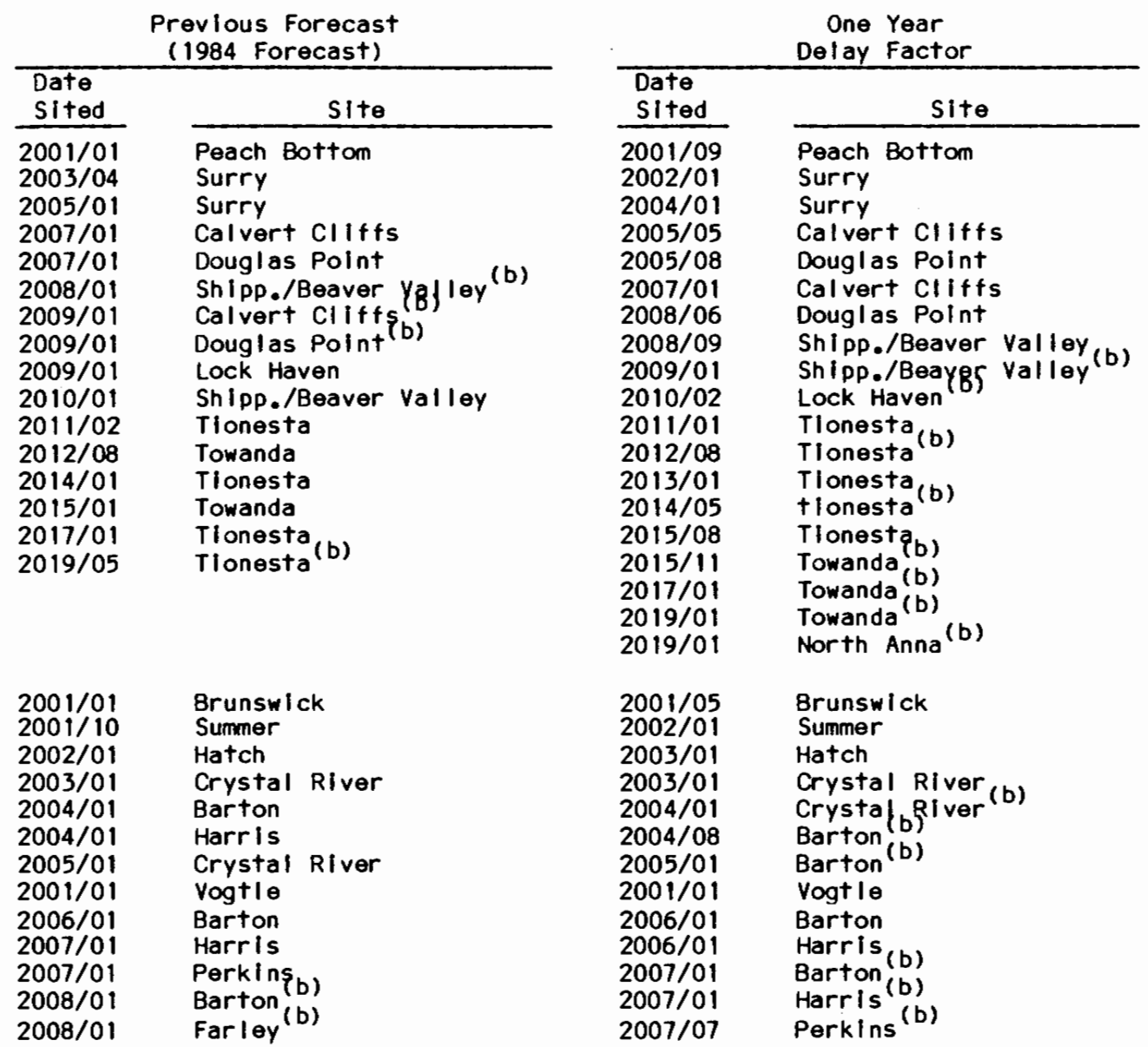

(a) Plants bullt in Region 2 to provide electriclty for Region 1.

(b) Plants sited in a difference sequence than in the Base Case. 
TABLE C.1. (contd)

General Sensitivity Cases

Federal Region
Base Case

(1985 Forecast)

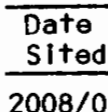

2008/01

$2008 / 0$

2008/01

2009/01

2009/0

$2009 / 0$

$2009 / 08$

$2009 / 08$

$20010 / 1$

$2010 \%$

2010/0

$2011 / 01$

$2011 / 01$

$2011 / 01$

(2011/06

$2011 / 12$

(2013/01

2013/0

2013/01

2013/01

2014/01

2014/01

2015/01

2015/01

2016/01

2016/06

2016/09

$2017 / 07$

2018/01

$2018 / 01$

2019/01

$2019 / 09$

$2020 / 01$

$2020 / 01$

$2020 / 11$

\begin{tabular}{l} 
Site \\
\hline Barton \\
Harris \\
McGuire
\end{tabular}

Perkins

Grand Gulf

Catawba

Cheroke日

St. Lucle

Barton

Hartsuille

Perkins

Cheroke日

St. Lucle

watts Bar

Bell efonte

Hartsuille

Cherokee

Watts Bar

Bell lefonte

Hartsullile

Browns Ferry

Watts Bar

Turkey Polnt

Yellow Creek

Hartsullle

Browns Ferry

Phlpps Bend

Turkey Point

Hartsulile

Yellow Creok

Phlpps Bend

Hartsville

Yellow Creek

Phipps Bend
Prevlous Forecast

(1984 Forecast)

\begin{tabular}{ll}
\hline $\begin{array}{c}\text { Date } \\
\text { Sited }\end{array}$ & \multicolumn{1}{c}{ Site } \\
& $\begin{array}{l}\text { Grand Gulf } \\
\text { 2009/01 }\end{array}$ \\
$2009 / 01$ & Harris
\end{tabular}

2009/01

2009/01

2009/01

2009/0

2010/01

2010/01

$2011 / 01$

$2011 / 01$

$2011 / 01$

2012/01

2012/01

2013/01

2013/01

2013/02

(2014/0

$2015 / 01$

$2015 / 01$

$2015 / 10$

$2017 / 0$

2018/03

2019/01

$2020 / 0$

2020/01

Harris

Perkins (b)

McGuire (b)

Cheroke日 (b)

Barton

Grand Gybf (b)

Perkins (b)

St. Lucle (b)

Watts Bar (b)

Hartsvil'(B)

St. Lucie ${ }^{(b)}$

Bellefonteb)

Watts Bar (b)

Bellefonte (b)

Bellefonte (b)

Browns Fef5Y

Hartsville (b)

Watts Bar

Hartsville (b)

Browns Ferry (b)

Turkey Point ${ }^{(b)}$

(a) Plants built in Region 2 to provide electriclty for Reglon 1.
(b) Plants sited in a difference sequence than in the Base Case. 
TABLE C.1. (contd)

General Sensitivity Cases

Federal

Reglon

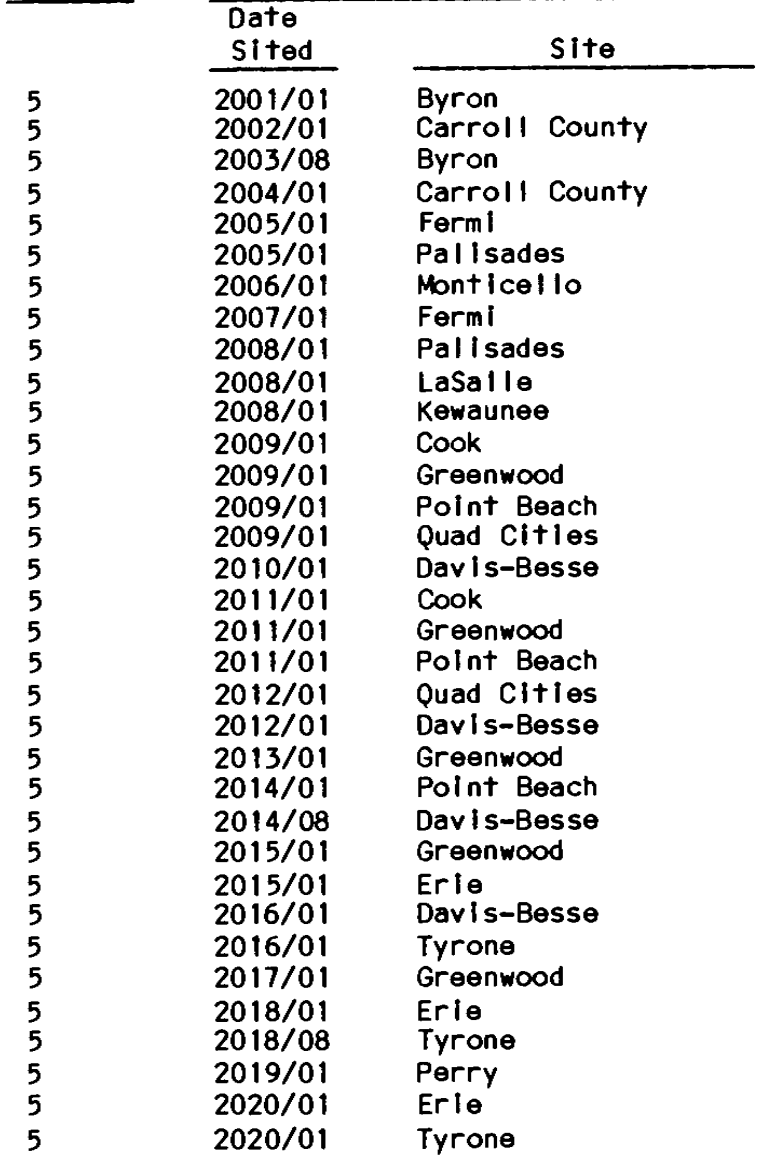

Previous Forecast

(1984 Forecast)

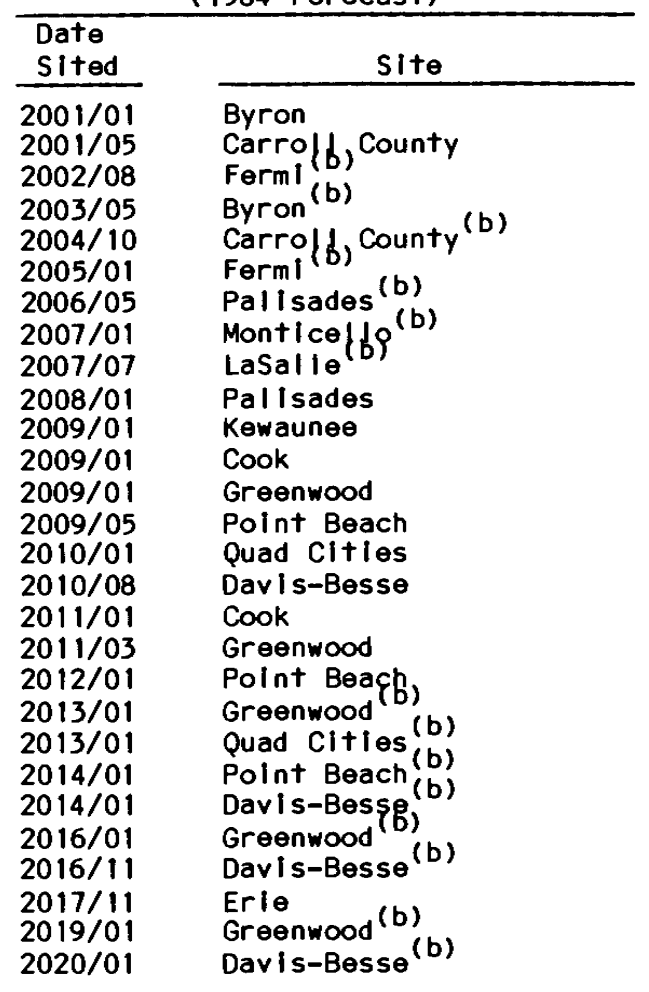

Delay Factor

\begin{tabular}{|c|c|}
\hline $\begin{array}{l}\text { Date } \\
\text { Sited } \\
\end{array}$ & site \\
\hline $\begin{array}{l}2001 / 01 \\
2002 / 01 \\
2003 / 08\end{array}$ & $\begin{array}{l}\text { Byron (a) } \\
\text { Byron } \\
\text { Carroll County (b) }\end{array}$ \\
\hline $\begin{array}{l}2004 / 01 \\
2005 / 01 \\
2005 / 01 \\
2006 / 01 \\
2007 / 01 \\
2008 / 01\end{array}$ & $\begin{array}{l}\text { Carroll County } \\
\text { Fermi } \\
\text { Pal Isages } \\
\text { Ferml } \\
\text { Pal Isades (b) } \\
\text { MontIcel lo }\end{array}$ \\
\hline $2008 / 01$ & $\begin{array}{l}\text { LaSalle } \\
\text { Kewaunee }\end{array}$ \\
\hline $\begin{array}{l}2009 / 01 \\
2009 / 01 \\
2009 / 01 \\
2009 / 01 \\
2010 / 01\end{array}$ & $\begin{array}{l}\text { Cook } \\
\text { Greenwood } \\
\text { Polnt Beach } \\
\text { Quad }(b) \text { ties } \\
\text { Cook }\end{array}$ \\
\hline $\begin{array}{l}2011 / 01 \\
2011 / 01 \\
2011 / 01\end{array}$ & $\begin{array}{l}\text { Greenwood } \\
\text { Polnt Beach(b) } \\
\text { Quad Cltigs? }\end{array}$ \\
\hline & $\begin{array}{l}\text { Greenwood (D) } \\
\text { Polnt Beach (b) }\end{array}$ \\
\hline $\begin{array}{l}2013 / 01 \\
2014 / 01\end{array}$ & $\begin{array}{l}\text { Greenwood (b) } \\
\text { Greenwood }\end{array}$ \\
\hline $\begin{array}{l}2014 / 08 \\
2015 / 01\end{array}$ & $\begin{array}{l}\text { Davis-Besse } \\
\operatorname{Davis-Besse}(b)\end{array}$ \\
\hline $\begin{array}{l}2015 / 01 \\
2016 / 01 \\
2016 / 01 \\
2017 / 01\end{array}$ & $\begin{array}{l}\text { Erle } \\
\text { DavişBesse } \\
\text { Erle } \\
\text { Davis-Besse (b) }\end{array}$ \\
\hline $\begin{array}{l}2018 / 01 \\
2018 / 08 \\
2019 / 01 \\
2020 / 01\end{array}$ & $\begin{array}{l}\text { Erle } \\
\text { Tyropg, } \\
\text { Erle (b) } \\
\text { Tyrone(b) } \\
\text { Perry (b) }\end{array}$ \\
\hline $2020 / 01$ & Perry \\
\hline
\end{tabular}

(a) Plants bullt in Reglon 2 to provide electricity for Region 1.

(b) Plants sited in a difference sequence than in the Base Case. 
TABLE C.1. (contd)

General Sensitivity Cases

Federal

Reglon

ir
Base Case

(1985 Forecast)

\begin{tabular}{l} 
Date \\
Sited \\
\hline
\end{tabular}

2003/01

2004/01

2006/05

$2008 / 01$

2009/01

2010/01

$2011 / 01$

2013/02

2016/01

$2017 / 01$

2019/01

Blue Hills

RIver Bend

BIue Hills

Blue HIlls

River Bend

Arkansas

Allens Creek

Arkansas

Allens Creek

South Texas

Waterford

2006/01

2009/01

2009/01

2013/01

2018/01

Arnold

Vandal la

Cooper

Cooper

Cal l away

None required

$\begin{array}{ll}2002 / 01 & \text { Mendocino } \\ 2003 / 01 & \text { San Onofre } \\ 2005 / 01 & \text { Mendoclino } \\ 2007 / 01 & \text { Mendocino } \\ 2008 / 01 & \text { San Onofre } \\ 2009 / 01 & \text { Mendocino } \\ 2010 / 01 & \text { San Onofre } \\ 2010 / 05 & \text { Rancho Seco } \\ 2012 / 01 & \text { San Onofre } \\ 2014 / 01 & \text { Rancho Seco } \\ 2014 / 01 & \text { Dlablo Canyon } \\ 2016 / 01 & \text { Dlablo Canyon } \\ 2018 / 01 & \text { Palo Verde } \\ 2018 / 05 & \text { Sundesert }\end{array}$

Prevlous Forecast

(1984 Forecast)

\begin{tabular}{l} 
Date \\
Sited \\
\hline
\end{tabular}

2002/10

$2005 / 07$

2007/08

2009/01

2009/01

2009/08

(2011/01

$2013 / 01$

$2014 / 08$

2018/01

Blue HIIIs (b)

Blue Hills
Blue HIIIs

River Bepd (b)

Arkansas

Allens Creek (b)

River Bend

Arkansas

Allens Creek

South Texas

2006/01

2009/01

$2011 / 01$

2014/09

Arnold

Vandalla

Cooper

Cooper

Call away

None required

$\begin{array}{ll}2002 / 01 & \text { Mendocino }(b) \\ 2005 / 01 & \text { Mendocino } \\ 2007 / 01 & \text { Mendocino }(b) \\ 2008 / 01 & \text { San Onofre } \theta_{b} \\ 2009 / 01 & \text { Mendocino }(b) \\ 2010 / 01 & \text { San Onofre }(a) \\ 2011 / 01 & \text { Rancho Secp(a) } \\ 2012 / 01 & \text { San Onofre } \\ 2014 / 01 & \text { San Onofre } \\ 2016 / 01 & \text { Rancho Seco } \\ 2019 / 01 & \text { Dlablo Canyon }\end{array}$

One Year

Delay Factor

\begin{tabular}{|c|c|}
\hline $\begin{array}{l}\text { Date } \\
\text { Sited }\end{array}$ & site \\
\hline $\begin{array}{l}2003 / 01 \\
2004 / 01 \\
2006 / 05 \\
2008 / 01 \\
2009 / 01\end{array}$ & $\begin{array}{l}\text { Blue Hills } \\
\text { Blue Hills }(b) \\
\text { Blue Hills } \\
\text { RIver Bend }(b) \\
\text { River Bend }\end{array}$ \\
\hline $\begin{array}{l}2010 / 01 \\
2011 / 01 \\
2012 / 01 \\
2013 / 02 \\
2016 / 01 \\
2017 / 01 \\
2019 / 01\end{array}$ & $\begin{array}{l}\text { Arkansas (b) } \\
\text { Arkansas } \\
\text { Allens Creek (b) } \\
\text { Allens Creek } \\
\text { South Texas (b) } \\
\text { South Texas) } \\
\text { Waterford }\end{array}$ \\
\hline $\begin{array}{l}2006 / 01 \\
2006 / 02 \\
2009 / 01 \\
2013 / 01 \\
2013 / 01 \\
2018 / 01\end{array}$ & $\begin{array}{l}\text { Arnold } \\
\text { Vandall a } \\
\text { Cooper } \\
\text { Cooper } \\
\text { Cal laway } \\
\text { Cal l away }\end{array}$ \\
\hline
\end{tabular}

None required

$\begin{array}{ll}2002 / 01 & \text { Mendocino }(b) \\ 2003 / 01 & \text { Mendocino } \\ 2005 / 01 & \text { Mendocino } \\ 2007 / 01 & \text { Mendocino } \\ 2008 / 01 & \text { San Onofre } \\ 2009 / 01 & \text { San Onofre } \\ 2010 / 01 & \text { San Onofre } \\ 2010 / 05 & \text { Rancho Seco } \\ 2012 / 01 & \text { San Onofre } \\ 2014 / 01 & \text { Rancho Seco } \\ 2014 / 01 & \text { Dlablo Canyon } \\ 2016 / 01 & \text { Diablo Canyon } \\ 2018 / 01 & \text { Palo Verde } \\ 2018 / 05 & \text { Sundesert }\end{array}$

(a) Plants built in Reglon 2 to provide electricity for Reglon 1.

(b) Plants sited in a difference sequence than in the Base Case. 
TABLE C.1. (contd)

\begin{tabular}{|c|c|c|c|c|c|c|c|}
\hline \multirow[t]{2}{*}{$\begin{array}{l}\text { Federal } \\
\text { Reglon }\end{array}$} & \multicolumn{2}{|c|}{$\begin{array}{c}\text { Base Case } \\
\text { (1985 Forecast) }\end{array}$} & \multicolumn{2}{|r|}{$\begin{array}{l}\text { Prevlous Forecast } \\
\text { (1984 Forecast) }\end{array}$} & \multicolumn{3}{|c|}{$\begin{array}{c}\text { One Year } \\
\text { Delay Factor }\end{array}$} \\
\hline & $\begin{array}{l}\text { Date } \\
\text { Sited }\end{array}$ & site & $\begin{array}{l}\text { Date } \\
\text { Sited }\end{array}$ & site & $\begin{array}{l}\text { Date } \\
\text { Sited }\end{array}$ & & Site \\
\hline $\begin{array}{l}10 \\
10 \\
10 \\
10 \\
10 \\
10 \\
10 \\
10\end{array}$ & $\begin{array}{l}2002 / 08 \\
2004 / 02 \\
2008 / 01 \\
2009 / 01 \\
2011 / 01 \\
2013 / 01 \\
2015 / 01 \\
2017 / 01\end{array}$ & $\begin{array}{l}\text { Hanford } \\
\text { Hanford } \\
\text { Hanford } \\
\text { Satsop } \\
\text { Skagit } \\
\text { Skagit } \\
\text { Skagit } \\
\text { Skagit }\end{array}$ & $\begin{array}{l}2005 / 01 \\
2008 / 01 \\
2010 / 01 \\
2012 / 01 \\
2016 / 01 \\
2020 / 09\end{array}$ & $\begin{array}{l}\text { Hanford } \\
\text { Hanford } \\
\text { Hanford } \\
\text { Satsop } \\
\text { Skagit } \\
\text { Skagit }\end{array}$ & $\begin{array}{l}2002 / 08 \\
2004 / 02 \\
2008 / 01 \\
2009 / 01 \\
2011 / 01 \\
2013 / 01 \\
2015 / 01 \\
2017 / 01\end{array}$ & $\begin{array}{l}\text { Hanford } \\
\text { Hanford } \\
\text { Hanford } \\
\text { Satsop } \\
\text { Skagit } \\
\text { Skagit } \\
\text { Skagit } \\
\text { Skagit }\end{array}$ & \\
\hline
\end{tabular}

(a) Plants bullt in Reglon 2 to provide electricity for Reglon 1.

(b) Plants sited in a difference sequence than in the Base Case. 
TABLE C.2. Postulated Sequence of Generic Plant Assignments to Potential Sites (Site Characteristic Sensitivity Cases)

Site Characteristic Sensitivity Cases

\begin{tabular}{|c|c|c|c|c|c|c|}
\hline \multirow[t]{2}{*}{$\begin{array}{l}\text { Federal } \\
\text { Region }\end{array}$} & \multicolumn{2}{|c|}{$\begin{array}{c}\text { Base Case } \\
\text { (1985 Forecast) }\end{array}$} & \multirow[t]{2}{*}{$\begin{array}{r}\text { Reduced Cooling } \\
\text { Hater Importance } \\
\end{array}$} & \multirow[t]{2}{*}{$\begin{array}{l}\text { Reduced Land Area } \\
\text { Importance }\end{array}$} & \multirow[t]{2}{*}{$\begin{array}{c}\text { Doubled Power } \\
\text { Iransmtssion Importance } \\
\end{array}$} & \multirow[t]{2}{*}{$\begin{array}{l}\text { Doubled Metropolitan } \\
\text { Proximity Importance } \\
\end{array}$} \\
\hline & $\begin{array}{l}\text { Date } \\
\text { Sited } \\
\end{array}$ & Site & & & & \\
\hline $\begin{array}{l}1 \\
1 \\
1 \\
1 \\
1 \\
1 \\
1 \\
1 \\
1 \\
2(a) \\
2(b)\end{array}$ & $\begin{array}{l}2003 / 03 \\
2007 / 01 \\
2008 / 01 \\
2009 / 01 \\
2010 / 01 \\
2011 / 01 \\
2012 / 03 \\
2015 / 01 \\
2016 / 01 \\
2018 / 01 \\
2020 / 07\end{array}$ & $\begin{array}{l}\text { Maine Yankee } \\
\text { Montague } \\
\text { MEPCO (Charlestown) } \\
\text { Montague } \\
\text { NEPCO (Charlestown) } \\
\text { Vermont Yankee } \\
\text { Connectlcut Yankee } \\
\text { P1lgrim } \\
\text { Ptlgrim } \\
\text { Greene County } \\
\text { Greene County }\end{array}$ & $\begin{array}{l}\text { Malne Yankee } \\
\text { Mantague } \\
\text { MEPCO (Charlestown) } \\
\text { Montague } \\
\text { MEPCO (Charlestown) } \\
\text { Vermont Yankee } \\
\text { Connecticut Yankee } \\
\text { Pilgrim } \\
\text { Pilgrim } \\
\text { Greene County } \\
\text { Greene County }\end{array}$ & $\begin{array}{l}\text { Malne Yankee } \\
\text { Vermont Yankee(b) } \\
\text { Montague (b) } \\
\text { NEPCO (Charl lestown)(b) } \\
\text { Montague(b) } \\
\text { MEPCO (Charlestown) (b) } \\
\text { Connecticut Yankee } \\
\text { Pilgrim } \\
\text { PIlgrim } \\
\text { Greene County } \\
\text { Greene County }\end{array}$ & $\begin{array}{l}\text { Maine Yankee } \\
\text { Montague } \\
\text { MEPCO (Charlestown) } \\
\text { Montague } \\
\text { MEPCO (Charlestown) } \\
\text { Vermont Yankee } \\
\text { Connecticut Yankee } \\
\text { Pilgrim } \\
\text { Pilgrim } \\
\text { Greene County } \\
\text { Greene County }\end{array}$ & $\begin{array}{l}\text { Maine Yankee } \\
\text { Vermont Yankee }(b) \\
\text { Montague }(b) \\
\text { MEPCO (Charlestown(b) } \\
\text { Montague (b) } \\
\text { NEPCO (Charlestown)(b) } \\
\text { Connecticut Yankee } \\
\text { Pflgrim } \\
\text { PIlgrim } \\
\text { Greene County } \\
\text { Greene County }\end{array}$ \\
\hline $\begin{array}{l}2 \\
2 \\
2 \\
2 \\
2 \\
2 \\
2 \\
2 \\
2 \\
2 \\
2 \\
2 \\
2 \\
2\end{array}$ & $\begin{array}{l}2001 / 01 \\
2002 / 03 \\
2005 / 01 \\
2007 / 01 \\
2007 / 12 \\
2009 / 01 \\
2010 / 01 \\
2010 / 01 \\
2012 / 01 \\
2013 / 01 \\
2014 / 01 \\
2016 / 01 \\
2017 / 11 \\
2018 / 01\end{array}$ & $\begin{array}{l}\text { Salem/Hope Creek } \\
\text { Atlantic } \\
\text { Salem/Hope Creek } \\
\text { Atlantic } \\
\text { Nine Mile Pt./Fitz. } \\
\text { Glnna } \\
\text { Sterling } \\
\text { Shoreham } \\
\text { Sterling } \\
\text { Shoreham } \\
\text { Jamesport } \\
\text { Jamesport } \\
\text { Greene County } \\
\text { Jamesport }\end{array}$ & $\begin{array}{l}\text { Salem/Hope Creek } \\
\text { Atlantic } \\
\text { Salem/Hope Creek } \\
\text { Atlantic } \\
\text { Mine Nile Pt./Fitz. } \\
\text { Ginna } \\
\text { Sterling } \\
\text { Shoreham } \\
\text { Sterling } \\
\text { Shoreham } \\
\text { Jamesport } \\
\text { Jamesport } \\
\text { Greene County } \\
\text { Jamesport }\end{array}$ & $\begin{array}{l}\text { Salem/Hope Creek } \\
\text { Atlantic } \\
\text { Salem/Hope Creek } \\
\text { Atlantic } \\
\text { Nine Mile Pt./Fitz. } \\
\text { Ginna } \\
\text { Sterling } \\
\text { Shoreham } \\
\text { Sterling } \\
\text { Shoreham } \\
\text { Jamesport } \\
\text { Jamesport } \\
\text { Greene County } \\
\text { Jamesport }\end{array}$ & $\begin{array}{l}\text { Salem/Hope Creek } \\
\text { Atlantic } \\
\text { Salem/Hope Creek } \\
\text { Atlantic } \\
\text { Nine Mile Pt./Fitz. } \\
\text { Ginna } \\
\text { Shoreham(b) } \\
\text { Sterilng (b) } \\
\text { Shoreham (b) } \\
\text { Sterling(b) } \\
\text { Jamesport } \\
\text { Jamesport } \\
\text { Oyster Cr./Forked R.(b) } \\
\text { Jamesport }\end{array}$ & 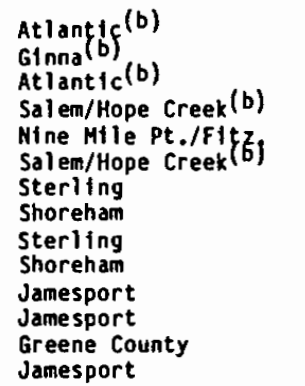 \\
\hline
\end{tabular}

(a) Plants built in Region 2 to provide electrictty for Reglon 1.

(b) Plants sited in a difference sequence than in the Base Case. 
TABLE C.2. (contd)

Site Characteristic Sensitivity Cases

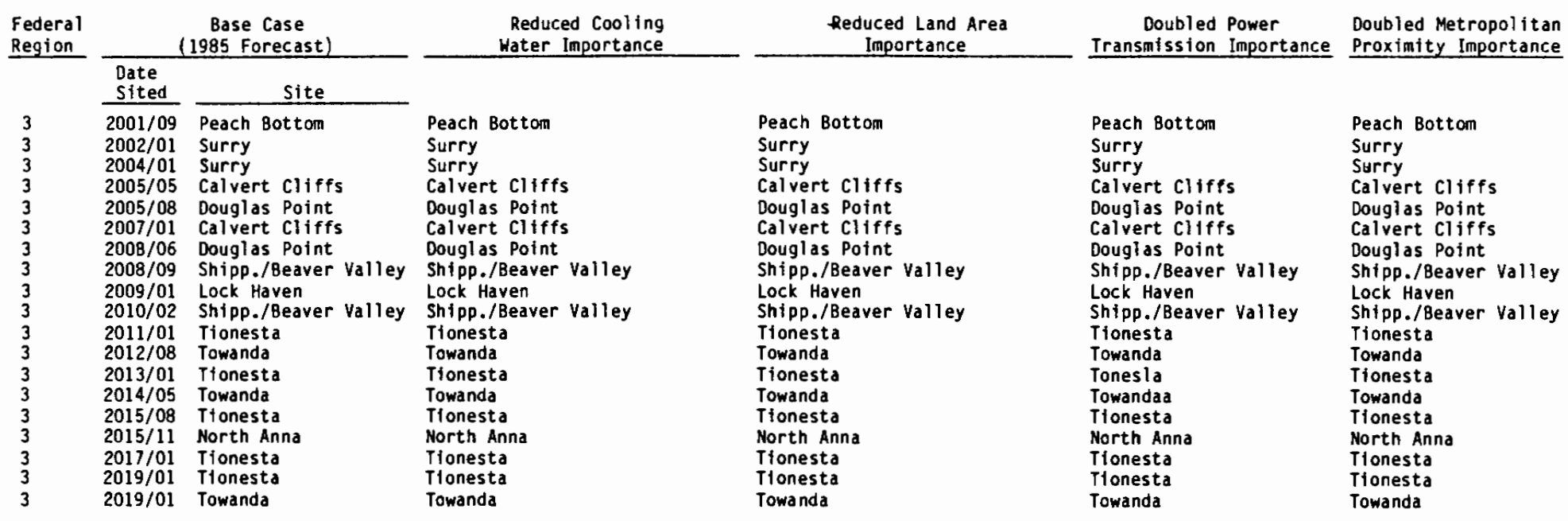

(a) Plants built in Region 2 to provide electricity for Region 1.

(b) Plants sited in a difference sequence than in the Base Case. 
TABLE C.2. ( contd)

Site Characteristic Sensitivity Cases

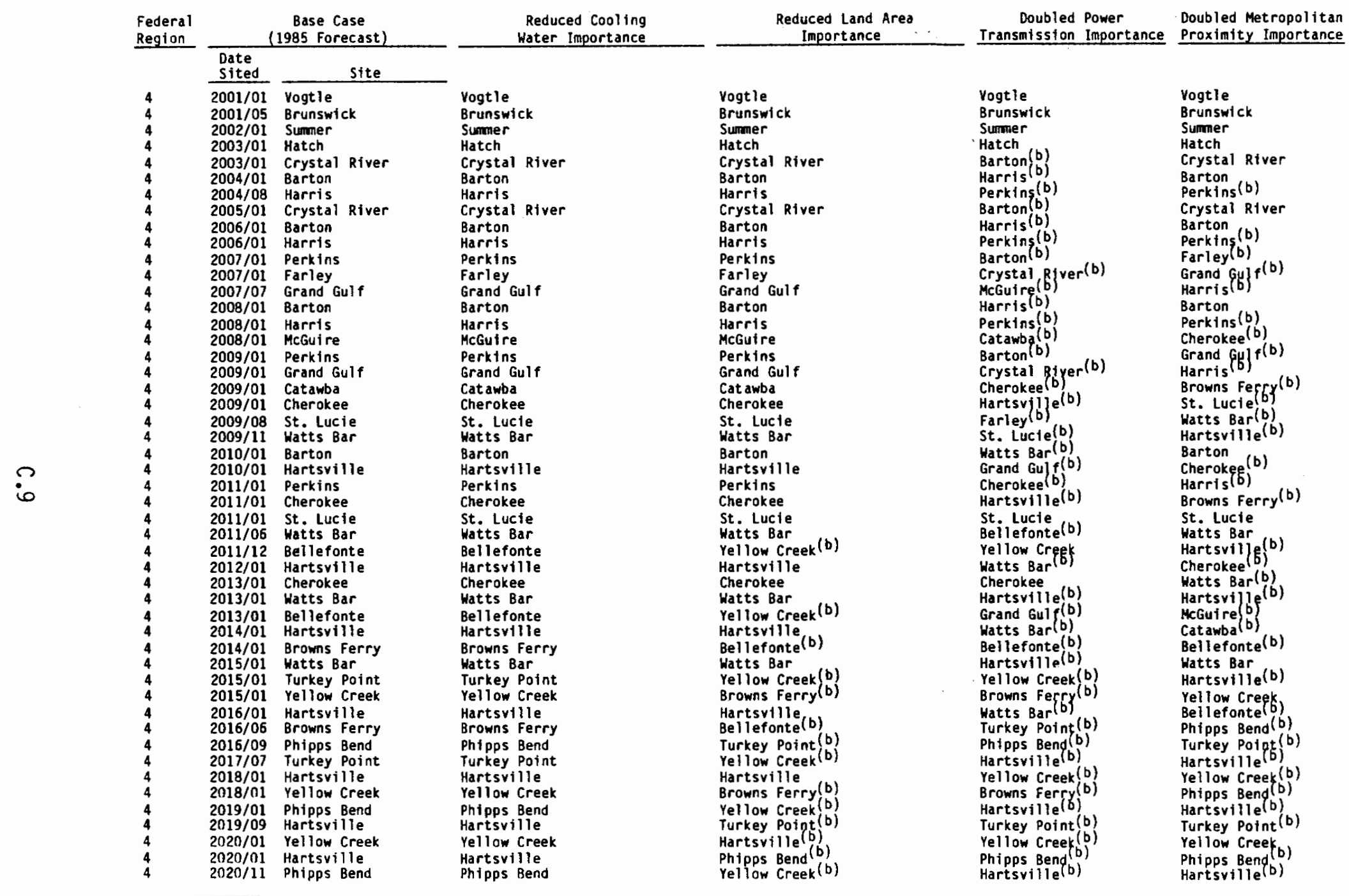

(a) Plants built in Region 2 to provide electricity for Region 1.
(b) Plants sited in a difference sequence than in the Base Case. 
TABLE C.2. (contd)

S1te Characteristic Sensitivity Cases

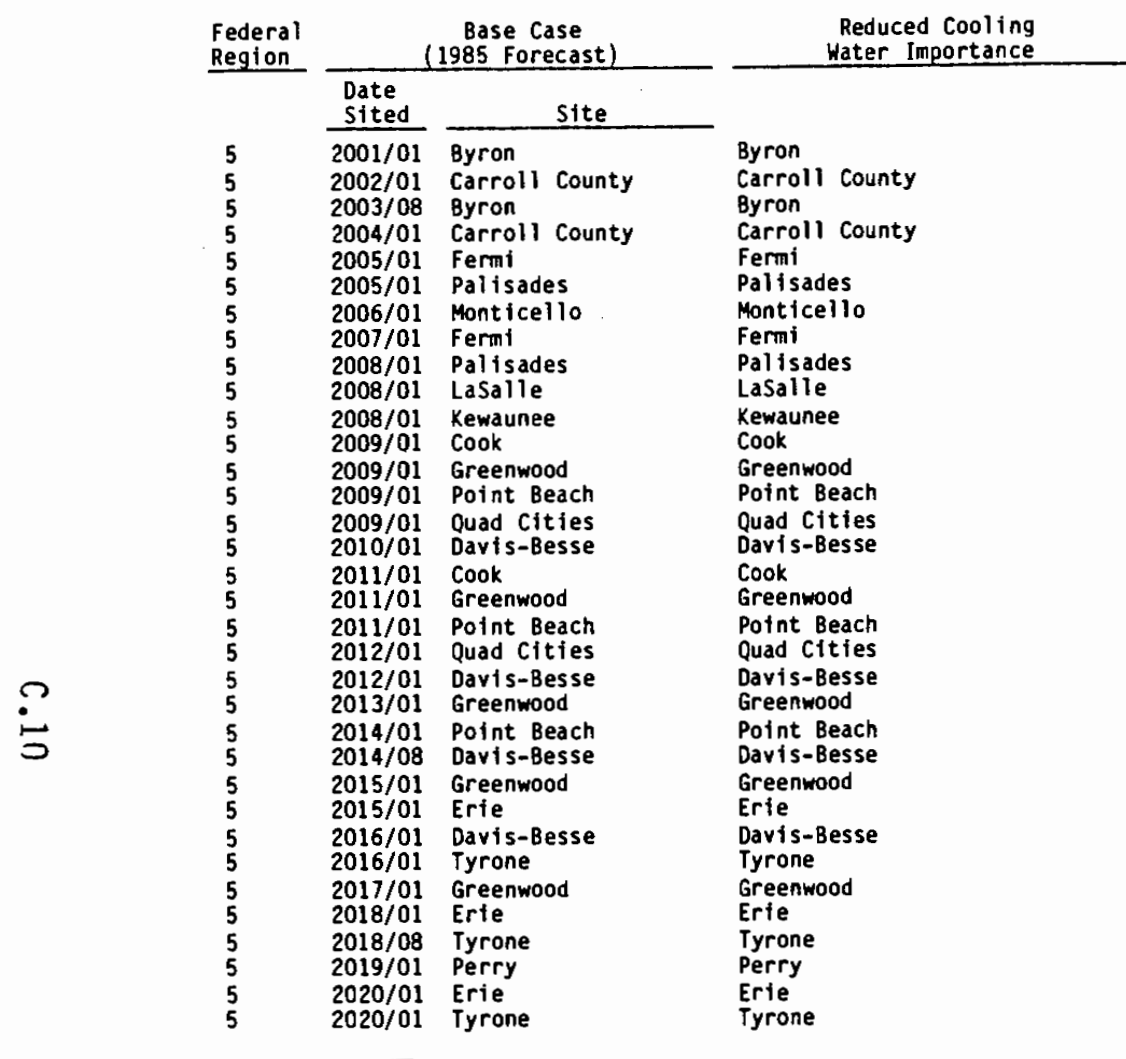

Reduced Land Area $\begin{gathered}\text { Doubled Power } \\ \text { Iransmission Importance }\end{gathered}$
Proximity Importance

Doubled Metropolitan Importance

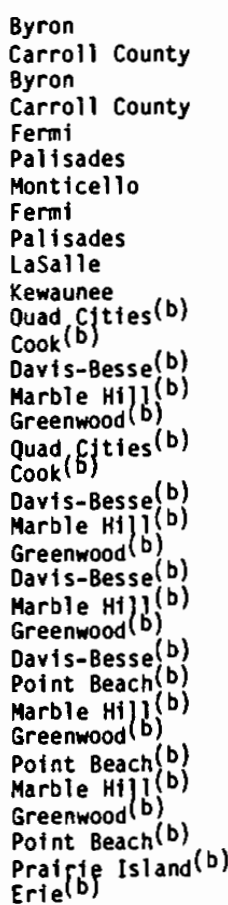

\begin{tabular}{|c|}
\hline 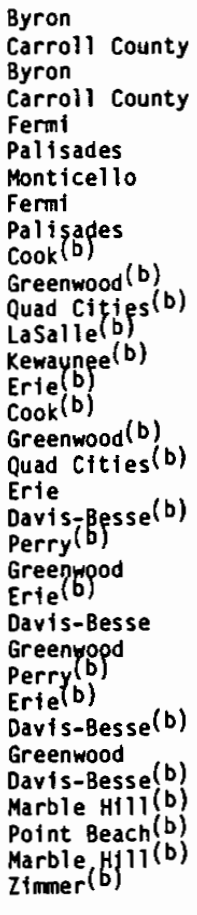 \\
\hline
\end{tabular}

Byran

Carroll County

Byron

Carroll founty

Kermi (b)

ermi (b)

Palisades

Monticeilo(b)

Point Beach(b)

Paltsajes

Cook (b)

Quad Citles

Point Beach $(b)$

cook (b)

Quad Cities (b)

Point Beach

Davis-Besse

Davis-Bess(b)

Prairie Island (b)

Marble Hill $(b)$

Davis-Besse

Pratrie Islang(b)

Davis-Besse

Prairie Island (b)

Greenwood $(b)$

(a) Plants built in Region 2 to provide electricity for Region 1. 
TABLE C.2. (contd)

Site Characteristic Sensitivity Cases

Federa

Region

$\frac{\begin{array}{c}\text { Base Case } \\ \text { (1985 Forecast) }\end{array}}{\frac{\text { Date }}{\text { Sited }} \frac{\text { Site }}{2003 / 01}}$

2004/01 River Bends

2008/01 Blue Hills

2009/01 River Bend

2010/01 Arkansas

2011/01 Allens Creek

2012/01 Arkansas

2013/02 Allens Creek

$2017 / 01$ waterford

2019/01 South Texas

2006/01 Arnold

2006/02 Vandalt

2009/01 Coope

2013/01 Call away

2018/01 Call awa

None required

(a) Plants built in Region 2 to provide electricity for Region 1.

(b) Plants sited in a difference sequence than in the Base Case.

Reduced Land Are Importance

Blue Hills
River Bend
Blue Hills
Blue Hills
River Bend
Arkansas
Allens Creek
Arkansas
Allens Creek
South Texas
Waterford
South Texas
Arnold
Vandalifa
Cooper
Cooper
Ft. Calhoun
Ft. Calhoun
None required

None required
Doubled Power Water Import ance

Blue Hills

Blue Hills

Blue Hills

River Bend
Arkansas

Allens Creek

Allens Cree

South Texas

Waterford

Arnold

Cooper

Cooper

Callaway

None requited
Doubled Metropolitan Iransmission Importance Proximity Importance

Blue Hills

Blue bills

Blue Hills

River Bend

Arkansas

Allens Creek

Arkansas

Allens Creek

Waterford

Vandalja(b)

Cooper

Ft. Calhoun (b)

Blue Hills,
Arkansas (5)

Blue Hills

Blue Hills

Arkansas (b) (b)

South Texas (b)

River Bend (b)

South Texas (b)
Allens Creek (b)

Haterford

Waterford (b)

Arnold

Vandalia

Cooper

Callaway

Callaway

None required

None required 
TABLE C.2. (contd)

Site Characteristic Sensitivity Cases

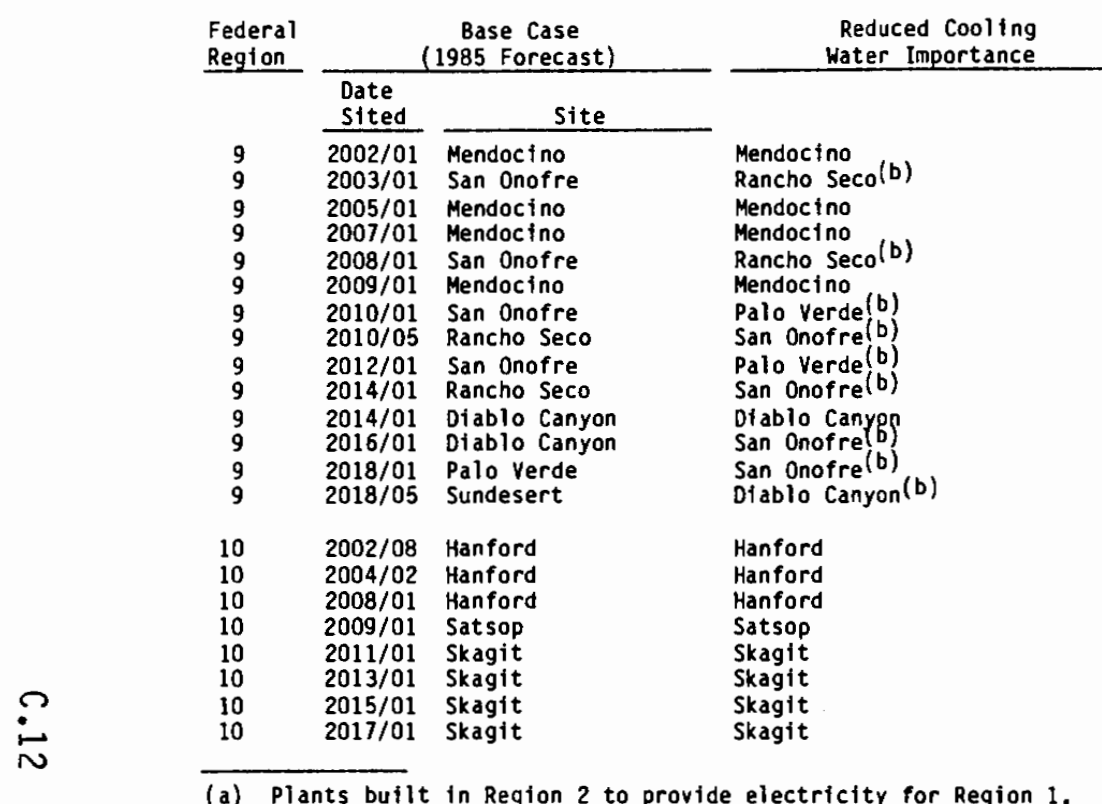

Reduced Land Are Importance

Mendocino
San Onofre
Mendocino
Mendocino
San Onofre
Mendocino
San Onofre
Rancho Seco
San Onofre
Rancho Seco
Diablo Canyon
Diablo Canyon
Palo Verde
Sundesert
Hanford
Hanford
Hanford
Satsop
Skagit
Skagit
Skagit
Skagit

Doubled Powe Doubled Metropolitan Iransmission Importance Proximity Importance

Mendocino
San Onofre
Mendocino
Mendocino
San Onofre
Mendocino
San Onofre
Rancho Seco
San Onofre
Rancho Seç
Palo Verde $($ b)
Palo Verde (b)
Diablo Canyon (b)
Sundesert
Hanford
Hanford
Hanford
Satsop
Skagit
Skagit
Skagit
Skagit

Mendocino

Rancho Seco (b)

Mendocino

Rancho Seco (b)

Mendocino

Diablo Canyge(b)

Diablo Canyon (b)

San Onofre

Palo Verde (b)

San Onofre (b)

alo Verde

Hanford

Hanford

Satsop

Pebble Springs (a)

Pebble Springs $(a)$

Skagit

Skagit

(b) Plants sited in a difference sequence than in the Base Case. 


\section{DISTRIBUTION}

No. of

Copies

OFFSITE

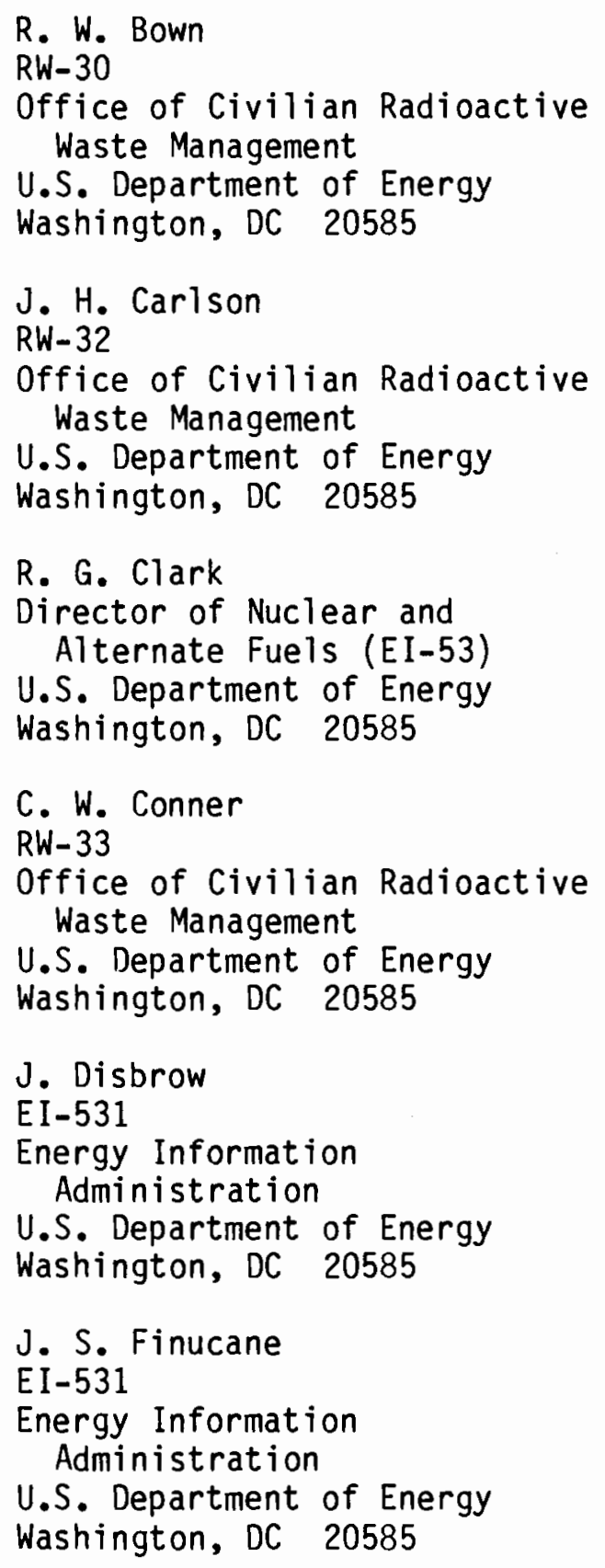

No. of

Copies

W. A. Frankhauser

DP-122.1

U.S. Department of Energy

Washington, DC 20545

J. R. Hilley

$\mathrm{RW}-30$

Office of Civilian Radioactive Waste Management

U.S. Department of Energy

Washington, DC 20585

T. H. Issacs

RW-42

Office of Civilian Radioactive Waste Management

U.S. Department of Energy

Washington, DC 20585

K. A. Klein

RW-32

Office of Civilian Radioactive Waste Management

U.S. Department of Energy

Washington, DC 20585

E. F. Mastel

$\mathrm{NE}-72$

U.S. Department of Energy

Washington, DC 20545

R. A. Milner

$\mathrm{RW}-12$

U.S. Department of Energy

Washington, DC 20545

T. D. Nguyen

$\mathrm{RW}-33$

Office of Civilian Radioactive Waste Management

U.S. Department of Energy

Washington, DC 20585 
No of

Copies

M. L. Payton

$\mathrm{RW}-12$

Office of Civilian Radioactive Waste Management

U.S. Department of Energy

Washington, DC 20585

R. Philpott

$\mathrm{RW}-12$

Office of Civilian Radioactive Waste Management

U.S. Department of Energy

Washington, DC 20585

D. E. Shelor

$\mathrm{RW}-32$

Office of Civilian Radioactive Waste Management

U.S. Department of Energy

Washington, DC 20585

H. Steinberg

$\mathrm{RW}-33$

Office of Civilian Radioactive Waste Management

U.S. Department of Energy

Washington, DC 20585

W. M. Sprecher

$\mathrm{RW}-42$

Office of Civilian Radioactive Waste Management

U.S. Department of Energy

Washington, DC 20585

E. L. Wilmot

$\mathrm{RW}-33$

Office of Civilian Radioactive Waste Management

U.S. Department of Energy

Washington, DC 20585

J. A. Klein

Oak Ridge National Laboratory

P.O. Box $X$

Oak Ridge, TN 37830

30

DOE Technical Information Center
No. of

Copies

Ken Golleher

DOE Albuquerque Operations Office

P.0. Box 5400

Albuquerque, NM 87115

G. C. Allen

Sandia National Laboratories

P.0. Box 5800

Albuquerque, NM 87185

J. W. Cashwell

Sandia National Laboratories

P.0. Box 5800

Albuquerque, NM 87185

E. R. Johnson

JAI

11702 Bowman Green

Reston, VA 22090

R. Piscetella

EG\&G Idaho

P.0. Box 1625

Idaho Falls, ID 83415

R. W. Lambert

Electric Power Research

Institute

3412 Hillview Avenue

Palo Alto, CA 94303

R. F. Williams

Electric Power Research

Institute

3412 Hillview Avenue

Palo Alto, CA 94303

Frank Haines

Roy $F$. Weston

2301 Research Blvd. Third Floor

Rockville, MD 20850

S. K. Gupta

Battel le Puget Management

Division

505 King Ave.

Columbus, $\mathrm{OH}$ 43201-2693 


No of
Copies
ONSITE
6 DOE Richland Operations Office
D. E. Crouter
R. D. Izatt (2)
D. C. Langstaff
J. M. Peterson
J. J. Sutey
62 Pacific Northwest Laboratory
M. K. Altenhofen
G. H. Beeman
J. L. Braitman
L. L. Clark
B. M. Cole
C. A. Counts
J. W. Currie
P. M. Daling
A. L. Doherty
K. A. Ekblaw
R. L. Engel
J. F. Fletcher
C. M. Heeb
G. M. Holter (10)

No. of

Copies

C. J. Hostick

C. H. Imhoff

G. J. Konzek

R. A. Libby

R. W. McKee

G. W. McNair

D. F. Newman

P. T. Ot is

J. S. Pomykala

W. L. Purcel 1

R. G. Rau

J. M. Reilly

N. L. Scharnhorst

K. J. Schneider

M. E. Schutz

M. R. Shay

S. M. Short

R. I. Smith

M. B. Triplett

R. C. Walling (10)

M. K. White

T. W. Wood

J. R. Young

Publishing Coordination MH (2)

Technical Information (5) 
